\title{
Health Inequalities
}

\section{and Social Determinants}

\section{of Aboriginal Peoples' Health}

Charlotte Loppie Reading Ph.D. University of Victoria
Fred Wien Ph.D.

Dalhousie University

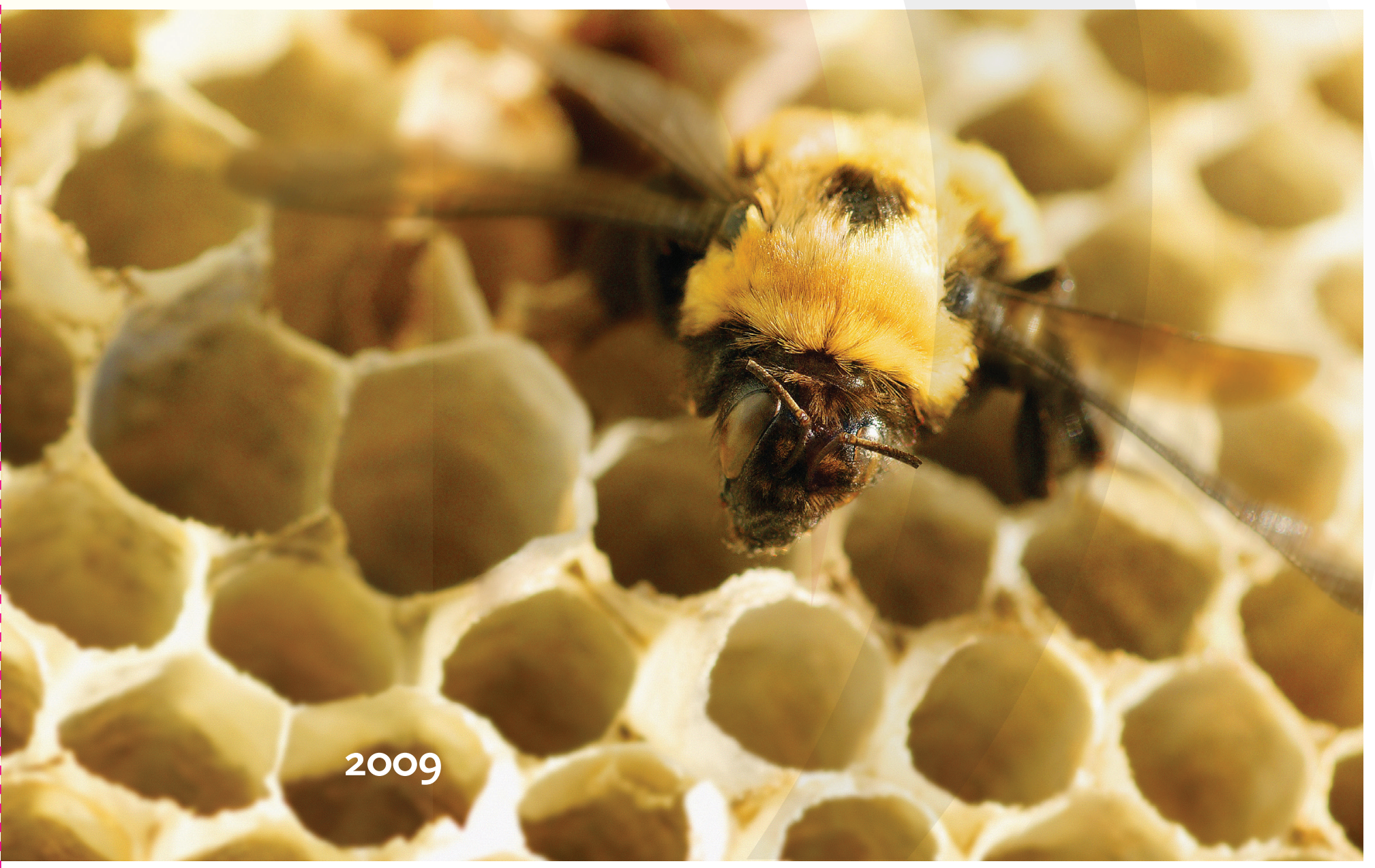





\section{HeAlth InEquAlities AND Social Determinants \\ of Aboriginal Peoples' Health}

Charlotte Loppie Reading PhD

University of Victoria
Fred Wien Ph.D.

Dalhousie University 


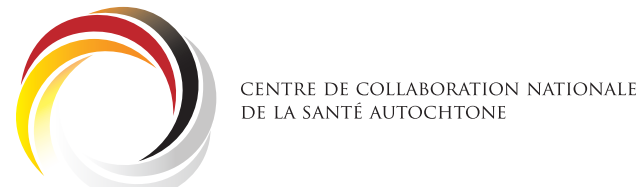

(C) 2009 - 2010 National Collaborating Centre for Aboriginal Health, NCCAH.

The National Collaborating Centre for Aboriginal Health supports a renewed public health system in Canada that is inclusive and respectful of diverse First Nations, Inuit and Métis peoples. The NCCAH is funded by the Public Health Agency of Canada and hosted at the University of Northern British Columbia, in Prince George, B.C. Production of this report has been made possible through a financial contribution from the Public Health Agency of Canada. The views expressed herein do not necessarily represent the views of the Public Health Agency of Canada.

National Collaborating Centre for Aboriginal Health University of Northern British Columbia

3333 University Way

Prince George, BC V2N 4Z9

For more information:

Email: nccah@unbc.ca

Web: www.nccah.ca

Office: 1-250-960-5250 


\section{Table of Contents}

Health Inequalities and Social Determinants

of Aboriginal Peoples' Health 1

Introduction 1

Social Determinants of Aboriginal Health $\quad 1$

Socio-Political Context 2

A Holistic Perspective of Health 3

Life Course - Child, Youth and Adult 3

A Note on the Adequacy of Aboriginal Public Health Data 4

Proximal Determinants of Health 5

Health Behaviours 6

Physical Environments $\quad 8$

Employment and Income 9

Education $\quad 12$

$\begin{array}{ll}\text { Food Insecurity } & 14\end{array}$

$\begin{array}{ll}\text { Intermediate Determinants of Health } & 15\end{array}$

Health Care Systems $\quad 15$

Educational Systems 17

Community Infrastructure, Resources and Capacities 17

Environmental Stewardship $\quad 17$

Cultural Continuity 18

Distal Determinants of Health $\quad 20$

$\begin{array}{ll}\text { Colonialism } & 21\end{array}$

Racism and Social Exclusion $\quad 22$

Self-Determination $\quad 23$

$\begin{array}{ll}\text { Conclusion } & 24\end{array}$

Putting It Together: The Integrated Life Course and

Social Determinants Model of Aboriginal Health (ILCSDAH) 25

$\begin{array}{ll}\text { Appendices } & 27\end{array}$

References $\quad 33$

Table Sources $\quad 40$ 



\section{List of Tables}

TABLE 1 The Well-Being of Inuit, First Nation and Other Canadian Communities, 2001

TABLE 2 Self-reported Smoking by First Nation Adults on Reserve, by Aboriginal Adults Off-Reserve, and by Non-Aboriginal Adults in Canada

TABLE 3 Mothers Smoking During Pregnancy, First Nation on Reserve and Canada, 2002-03 (percent)

TABLE 4 First Nation Adults on Reserve Who Live in a Smoke-Free Home, 2002-03

TABLE 5 Repairs Required for Dwellings Located On Reserve (2002-03) and for Canada (2003)

TABLE 6 Percentage of Inuit, Métis, First Nation and Non-Aboriginal People Living in Crowded Dwellings, Canada, 2006

TABLE 7 Selected Labour Force Characteristics for the Aboriginal Identity Population in Canada, 15 Years and over, 2001 Census

TABLE 8 Selected Income Characteristics of the Aboriginal Identity Population in Canada, 15 years of Age and over, 2001 Census

TABLE 9 Percentage of Those Reporting Fair or Poor Health by Household Income among Off-reserve Aboriginal and non-Aboriginal Peoples, Canada, 2000/01

TABLE 10 Percentage of Those Experiencing a Major Depressive Episode in the Past Year by Household Income and Off-reserve Aboriginal Status, Canada, 2000/01

TABLE 11 Highest Level of Schooling Attained by the Aboriginal Identity Population in Canada, 15 years of age and over, 2001 Census

TABLE 12 Prevalence of Food Insecurity, by Level and Selected Characteristics, Household Population, Canada Excluding Territories, 1998-99 (Percent)

TABLE 13 Health Care Utilization and Access, Household Population Aged 15 or Older, by Off-reserve Aboriginal Status, Canada and the Northern Territories, 2000-01

TABLE 14 Barriers to Accessing Health Services, First Nation Adults Living On Reserve, 2002-03

TABLE 15 Connection to the Land

TABLE 16 Percentage of First Nations People Who Have Knowledge of an Aboriginal Language, by Age Groups, Canada 2001 and 2006

TABLE 17 Percentage of Inuit Population who Reported Inuktitut as Mother Tongue and as Home Language, and Knowledge of Inuktitut, Canada and Regions, 1996 and 2006

TABLE 18 Percentage of the Métis Population with Knowledge of an Aboriginal Language, by Age Groups, Canada, 2006

TABLE 19 Percentage of First Nation Adults Living on Reserve Who Consider Traditional Spirituality and Religion Important in Their Lives

TABLE 20 The Impact of Residential Schools on First Nation Adults Living on Reserve, 2002-03 
TABLE 21 Instances of Racism Experienced by First Nation Adults on Reserve and

Perceived Impact on Level of Self-Esteem, 2002-03

TABLE 22 Self-determination Indicators by Feelings of Depression and Sadness

for First Nation Adults Living on Reserve, 2002-03

\section{Appendixes}

TABLE 23 Most Frequent Long-Term Health Related Conditions among First Nations Children Living On Reserve, 2002-03

TABLE 24 Most Frequent Long-Term Health Related Conditions among First Nation Youth Living On Reserve, 2002-03

TABLE 25 Frequently-Occurring Long-term Health Conditions of First Nation Adults Living on Reserve, and Other Adults in Canada

TABLE 26 Body Mass Index, Household Population 15 years of Age

TABLE 27 Adults 15 years of Age and Over Who Have Suffered a Major Depressive Episode in the Last 12 Months by Off-Reserve Aboriginal Status (Percent)

TABLE 28 Percentage of First Nation Youth Living on Reserve who Report Feeling Sad, Blue or Depressed for Two Weeks or More in a Row

TABLE 29 Importance of Keeping, Learning or Relearning an Aboriginal Language, by Age Group, Métis Identity Non-reserve Population 15 years of Age and Over, 2001

TABLE 30 Who Helps Aboriginal Children Learn an Aboriginal Language (Canada, 2001)

TABLE 31 Residential School Attendance for Aboriginal Adults Living Off-Reserve, and for First Nation Adults Living On Reserve

TABLE 32 Residential School Attendance for Aboriginal Adults Living Off-Reserve, and for First Nation Adults Living On Reserve 


\section{Health Inequalities and Social Determinants of Aboriginal Peoples' Health}

\subsection{Introduction}

This paper uses available data to describe health inequalities experienced by diverse Aboriginal peoples in Canada. ${ }^{\mathrm{I}}$ The data are organized around social determinants of health across the life course and provide evidence that not only demonstrates important health disparities within Aboriginal groups and compared to non-Aboriginal people, but also links social determinants, at proximal, intermediate and distal levels, to health inequalities. The Integrated Life Course and Social Determinants Model of Aboriginal Health is introduced as a promising conceptual framework for understanding the relationships between social determinants and various health dimensions, as well as examining potential trajectories of health across the life course.

Data from diverse and often limited literature is provided to support claims made by the authors of this paper and others about health disparities among Aboriginal peoples and the degree to which inequalities in the social determinants of health act as barriers to addressing health disparities. Additional tables have been included in the appendices to further support data and discussion presented in the text.

\subsection{Social Determinants of Aboriginal Health}

Beyond a small number of seminal reports, little is known about the distinct influence of social determinants of health in the lives of Aboriginal peoples. Yet, it is clear that the physical, emotional, mental and spiritual dimensions of health among Aboriginal children, youth and adults are distinctly, as well as differentially, influenced by a broad range of social determinants ( $\mathrm{I}-\mathrm{I} 3)$. These include circumstances and environments as well as structures, systems and institutions that influence the development and maintenance of health along a continuum from excellent to poor. The social determinants of health can be categorized as distal (e.g. historic, political, social and economic contexts), intermediate (e.g. community infrastructure, resources, systems and capacities), and proximal (e.g. health behaviours, physical and social environment) (I4-I6).

I The term "Aboriginal" refers to individuals identify with at least one Aboriginal group, i.e. First Nation (North American Indian), Métis or Inuit (Eskimo), and/or those who report being a Treaty Indian or a Registered Indian as defined by the Indian Act of Canada and/or who are members of an Indian Band or First Nation (Statistics Canada, 2008). 
Social determinants influence a wide range of health vulnerabilities and capacities, health behaviours and health management. Individuals, communities and nations that experience inequalities in the social determinants of health not only carry an additional burden of health problems, but they are often restricted from access to resources that might ameliorate problems. Not only do social determinants influence diverse dimensions of health, but they also create health issues that often lead to circumstances and environments that, in turn, represent subsequent determinants of health. For instance, living in conditions of low income have been linked to increased illness and disability, which in turn represents a social determinant, which is linked to diminished opportunities to engage in gainful employment, thereby aggravating poverty (I7-20).

Researchers and those responsible for the development of health policies have reached tentative consensus about an extensive list of social determinants that influence the health of individuals, communities and populations. What remains less well articulated are the mechanisms and contexts through which social determinants influence health. Similarly, aside from health care systems, we know relatively little about the role social determinants of health play in addressing ill health. Researchers are just beginning to map out the complex interconnections that exist and are demonstrating those linkages empirically (9, II-I2).

\subsection{Socio-Political Context}

The impact of social determinants is manifest differently among the distinct Aboriginal groups in Canada, which are themselves distinct from other Indigenous groups globally. Among Aboriginal peoples, there are a number of similar historical and contemporary social determinants that have shaped the health and well-being of individuals, families, communities and nations (I, 2I). Historically, the ancestors of all three Aboriginal groups underwent colonization and the imposition of colonial institutions, systems, and lifestyle disruption. However, distinctions in the origin, form and impact of those social determinants, as well as the distinct peoples involved, must also be considered if health interventions are to be successful. For example, while the mechanisms and impact of colonization as well as historic and neo-colonialism are similar among all Aboriginal groups, particular policies such as the Indian Act have been patently deleterious to the lives and health of First Nations people. First Nations are unique in their relationship with the Canadian government with respect to provisions made under the Indian Act of 1876 , which included health care. The contemporary outcome of the colonial process can be seen in political, social and economic domains (22).

For First Nations, Inuit and, to a lesser extent Métis peoples, the colonial process has resulted in diminished self-determination and a lack of influence in policies that directly relate to Aboriginal individuals and communities. (23). All Aboriginal groups have suffered losses of land, language and socio-cultural resources. Racism, discrimination and social exclusion also represent shared experiences among Aboriginal groups, with Métis peoples often experiencing exclusion from First Nations and Inuit groups as well. 
Aboriginal peoples differentially experience economic disadvantage; Métis tend to experience higher levels of socio-economic status than First Nations, who fair generally better than Inuit peoples. In general, remote communities, whether they are Métis, Inuit, or First Nation, suffer from a lack of economic development that might help to ameliorate health problems related to socio-economic status (24).

\subsection{A Holistic Perspective of Health}

Indigenous ideologies embrace a holistic concept of health that reflects physical, spiritual, emotional and mental dimensions. However, it is the interrelatedness of these dimensions that is perhaps most noteworthy. It has become widely accepted in mainstream health literature and, to some extent, practice that a "silo" approach to prevention and treatment of ill-health fails to address the complexity of most health issues. This is particularly true for Aboriginal peoples, who have historically been collectivist in their social institutions and processes, specifically the ways in which health is perceived and addressed (25-29).

\subsection{Life Course - Child, Youth and Adult}

Health is not only experienced across physical, spiritual, emotional and mental dimensions, but is also experienced over the life course. A life-long trajectory of health begins during gestation, with the health profile and social determinants affecting the health resources for pregnant women. Early child development follows, in which the circumstances of the physical and emotional environment impact not only children's current health but sets the groundwork for future vulnerabilities and resiliencies (30-36).

In as much as social determinants impact children, youth and adults in similar ways, they tend to manifest as different health issues in each life stage. Initially, the early years can be conceptualized as two, overlapping phases of early and late childhood. The outcome of early and late child development is first evident in adolescence, when social determinants continue to impact the distinct elements of adolescent well-being. Like childhood, adulthood can be viewed as two, integrated phases, which distinguish elderhood as a life phase that has specific vulnerabilities and health potentials (30-36).

Social determinants not only have differential impact on health across the life course, but the ensuing health issues may themselves create conditions (i.e., determinants) that subsequently influence health. For instance, poverty is associated with increased substance use, which can lead to stressful family environments and diminished social support, which are linked to, among other things, depression (37-38).

Physical environments such as crowded housing conditions have been associated with stress in all three age groups (39-40). However, for adults, these conditions can also indirectly contribute to substance overuse and parenting difficulties, which may result in poor school performance among youth and children. This particular interaction of life-stage health issues begins with a social determinant, which contributes to the creation of an environment for 
youth and child development. If a less-than-optimal environment is present, children and youth will not only face obstacles to optimal physical, emotional, intellectual, and spiritual development, but the difficulties they encounter will also likely create additional stressors for families and communities. In this case, youth substance over-use and violence as well as behaviour problems in children have been linked to over-crowded living conditions (27)

\subsection{A Note on the Adequacy of Aboriginal Public Health Data}

Compared to the situation a couple of decades ago, there has been a significant increase in the quantity and quality of Aboriginal health data. The Aboriginal Peoples Survey (APS) (4I), for example, which was introduced by Statistics Canada in I99I, marked a significant step forward even though the number of health-related questions is limited in this generalpurpose survey. Additionally, the First Nations Regional Longitudinal Health Survey (FNRLHS) has provided a wealth of new information for the on-reserve population beginning in $1997(42-44)$.

As far as health survey information is concerned (we will turn to other types of data below), there are still important gaps and challenges which limit what we can do in this paper. Available data are:

- Fragmented in the sense that individual surveys do not comprehensively include all Aboriginal groups. Over time, the APS, for example, has become less inclusive. It is still quite valuable for the off-reserve population but for the most part is not carried out on reserve. The FNRLHS is quite good for the on reserve population but does not include First Nation off reserve, Inuit or Métis people.

- Often the pieces do not add together in that different authorities are responsible for different surveys and methodologies differ. Even if a concept is measured in more than one survey, questions may not be worded in the same way, and thus the results are not comparable.

- Important gaps in the survey information base remain. Statistics Canada routinely completes surveys on a whole host of issues, dealing with subjects like activity limitations, time use, and adaptation to new technologies, the aging population and transition to retirement, or public safety and the victims of crime. However, First Nation persons living on reserve are almost always excluded from the surveys, and the coverage of Aboriginal people living off reserve (including Métis and Inuit) may be too sparse for detailed analysis (especially at geographic units below the national or provincial/territorial).

Other kinds of public health data are also problematic. Smylie (2006) has worked with vital registration, health services, surveillance and infant/child health data. She identifies these issues, among others:

The lack of accurate and complete identification of Aboriginal persons and, indeed, the fact that Aboriginal affiliation is often not asked at all. 
- The fragmentation of data resulting from the fact that health systems differ according to Aboriginal ethnicity, geography (for example, on and off reserve), and jurisdiction (for example, provincial and federal).

- The use of substandard data sources and methodologies. For example, infant mortality rates for First Nation persons living on reserve are based on vital registration data of uneven quality from four Western provinces combined with data collected from nursing stations in other parts of the country. The resulting figures are deemed to be an underestimate, a statement that is based on comparisons to other data available for certain regions but collected according to a higher standard.

- The failure to include culturally relevant health measures, reflecting Indigenous perspectives.

These data limitations impose at least two limitations on this paper. First, they mean that we are seldom able to report comparable data for all the different Aboriginal groups on the same dimension. While this is possible using the census, which also permits comparison with the rest of the Canadian population, it is usually not possible with other data sources. Secondly, it means that we must avoid reporting some kinds of data, such as infant mortality rates or adult death rates, that would normally be included in this kind of report as outcome measures, but which, in the case of Aboriginal people, may be unreliable and lack external validity.

In short, while considerable progress on Aboriginal public health data has been made, what we have remains far short of the standard of data available for other Canadians. On the assumption that a high quality health information base is an important cornerstone for health research and for evidence-based public policy, this is an issue that should be of concern to the Public Health Agency of Canada.

\subsection{Proximal Determinants of Health}

According to the United Nations Human Development Index, which measures health through longevity, educational achievement, and adult literacy, First Nations people in Canada rank 63rd in the world (45). Likewise, the Community Well-Being (CWB) scale for First Nations, developed by Indian and Northern Affairs Canada, which measures education, labour force participation, income and housing, indicates that Aboriginal communities represent 65 of the Ioo unhealthiest Canadian communities (45).

Proximal determinants of health include conditions that have a direct impact on physical, emotional, mental or spiritual health. For example, in conditions of overcrowding, which are most profoundly experienced among the Inuit people, children often have little room to study or play, while adults have no private space to relax (46-47). In many cases, these conditions act as a stressor, which increases the likelihood of behavioural and learning difficulties in children and adolescents as well as substance abuse and other social problems among adults $(48-49)$. Similarly, family violence, which is experienced at one time or 
another by almost three-quarters of on-reserve First Nation women (50-5I), directly impacts all family dimensions of health, especially women's health, with a resultant negative impact on the physical and emotional health of children.

The mechanisms through which proximal determinants influence health are not well articulated in the literature. However, some researchers have made tentative suggestions, which seem to be supported by the epidemiology of Aboriginal health. Beyond creating minimal capacity to meet basic survival needs (i.e. poverty), unfavourable proximal determinants can contribute to stressors that in turn can generate or exacerbate health problems (52). Moreover, individuals acquire personal skills and resources for coping with health challenges and developing health behaviours throughout life. These skills and resources help people deal with challenges as well as cope with illness and injury (53-55) When proximal determinants of health do not support control over the basic material resources of life, choice, which is key to health, is denied.

TABLE 1

The Well-Being of Inuit, First Nation and Other Canadian Communities, 2001

\begin{tabular}{lll}
\hline Community Type & Average CWB Score 1991 & Average CWB Score 2001 \\
\hline Inuit & 0.63 & 0.69 \\
First Nations & 0.58 & 0.66 \\
Other Canadian & 0.77 & 0.81 \\
\hline
\end{tabular}

Some research suggests that health outcomes are influenced by the types of communities or neighbourhoods in which one lives. Indian and Northern Affairs Canada has created a Community Well-Being index which results in a composite score for a community based on the characteristics of its residents - specifically their income, education, housing quantity and quality, and labour force characteristics (participation and employment rates). Table I reveals that the Community Well-Being Score for First Nation and Inuit communities is well below that of other Canadian communities. However, analysis of the CWB Score over time shows that the score improves for all three types of communities. It also shows a small degree of convergence over the course of the I99I-200I period.

\subsection{Health Behaviours:}

Health behaviours represent a well-recognized proximal determinant of health. Among Aboriginal peoples, the most relevant health behaviours include the over or misuse of alcohol, which is related to increases in all-case mortalities (56), and excessive smoking, the health effects of which are clearly expressed in high rates of heart disease and increasing rates of lung cancer (57-60). Poor prenatal care as well as drinking and smoking during pregnancy have also been linked to poor physical, emotional, and intellectual development among Aboriginal children (6I). Finally, lack of exercise and poor diet has been associated with the 
epidemic of Type II Diabetes among Aboriginal adults and increasing rates among Aboriginal youth (62-64). These health behaviours must be considered within the socio-political context of Aboriginal peoples' health, lest an individualistic perspective predominate analysis.

TABLE 2

Self-reported Smoking by First Nation Adults on Reserve, by Aboriginal Adults Off-Reserve, and by Non-Aboriginal Adults in Canada

\begin{tabular}{llll}
\hline Smoking Status & First Nation On Reserve & Aboriginal Off Reserve & Non-Aboriginal \\
\hline Daily & 46.0 & 41.5 & 22.1 \\
Occasional & 12.8 & 9.9 & 4.4 \\
\hline
\end{tabular}

Aboriginal adults are more than twice as likely to smoke cigarettes as other adults in Canada (Table 2). We know from other data, as well, that the rate of smoking has declined substantially in the non-Aboriginal population but has remained relatively stable among Aboriginal adults. The implications of such high levels of smoking for lung and other kinds of cancers, and for breathing problems, are serious. ${ }^{2}$

TABLE 3

Mothers Smoking During Pregnancy, First Nation on Reserve and Canada, 2002-03 (percent)

\begin{tabular}{llc}
\hline Smoking Status & First Nation Mothers on Reserve & All Canadian Mothers \\
\hline Smoked during pregnancy & 36.6 & 19.4 \\
$\begin{array}{l}\text { Smoked > 10 cigarettes per day } \\
\text { during pregnancy }\end{array}$ & 15.0 & 5.3 \\
\begin{tabular}{l} 
Smoking in third trimester \\
\hline
\end{tabular} & 32.2 & 17.2 \\
\hline
\end{tabular}

First Nation mothers living on reserve are almost twice as likely to smoke during pregnancy compared to Canadian mothers generally, and this pattern continues for smoking more than Io cigarettes per day and smoking in the 3 rd trimester of pregnancy (Table 3).

TABLE 4

First Nation Adults on Reserve Who Live in a Smoke-Free Home, 2002-03

\begin{tabular}{ll}
\hline Smoke Free Status of Home & First Nation Adults on Reserve (per cent) \\
\hline Live in a smoke-free home & 47.6 \\
Do not live in a smoke-free home & 52.4 \\
\hline
\end{tabular}

More than half of First Nation adults living on reserve are subjected to tobacco smoke in their home from one or more smokers (Table 4).

2 The Aboriginal Peoples Survey defines adults as those 15 years of age and over. In the Regional Health Survey, adults are considered to be 18 years of age and over. 


\subsection{Physical Environments}

Physical environments play a primary role in determining the health of populations. Among Aboriginal peoples, physical environments that are largely detrimental to health have been imposed through historic dispossession of traditional territories as well as current reserve or settlement structures. The most pervasive outcomes of these structures include substantial housing shortages and poor quality of existing homes $(65-67)$. Lack of affordable housing has created situations of overcrowding in First Nation and Inuit communities as well as homelessness for Aboriginal people living in urban areas. Many on-reserve homes are overcrowded and lack appropriate ventilation, resulting in excessive mould, which has been implicated in several health problems including severe asthma and allergies among Aboriginal children (68-70).

Aboriginal peoples living in remote rural and reserve communities face considerable food insecurity related to challenges acquiring both market and traditional foods (7I-75). The cost of transporting market foods to remote communities means that healthy, nutritious food is not affordable to most families. Poverty not only limits the extent to which individuals and families can access market foods but also makes the costs associated with contemporary hunting out of reach for many (76-78). Finally, poor sanitation and waste management, unsafe water supplies, and lack of community resources represent physical conditions that jeopardize the health of Aboriginal peoples (79).

TABLE 5

Repairs Required for Dwellings Located On Reserve (2002-03) and for Canada (2003)

\begin{tabular}{lll}
\hline Type of Repairs Needed & Dwellings on Reserve & Canadian Dwellings \\
\hline Major repairs & 33.6 & 7.5 \\
Minor repairs & 37.7 & 26.9 \\
Regular maintenance only & 24.0 & 65.6 \\
\hline
\end{tabular}

The quality of the housing stock in a community has been shown to be an important determinant of health. The poor condition of dwellings located on reserve is demonstrated in Table 5, which shows that a third of the housing stock is in need of major repairs, compared to only 8 per cent of Canadian dwellings. 3 Other data from the First Nations Regional Longitudinal Health Survey reveals that almost half of the respondents indicated there was mould or mildew in the home in the I2 months preceding the survey (57).

3 Dwellings in need of major repairs are those that, in the judgement of the respondent, require major repairs to such things as defective plumbing or electrical wiring, and/or structural repairs to walls, floors or ceilings, etc. 
TABLE 6

Percentage of Inuit, Métis, First Nation and Non-Aboriginal People Living in Crowded Dwellings, Canada, 2006

\begin{tabular}{lllll}
\hline Housing Condition & Inuit & Métis & First Nation & Non-Aboriginal \\
\hline Living in Crowded Dwellings & 31 & 3 & 15 & 3 \\
$\begin{array}{l}\text { Living in Dwellings in Need } \\
\text { Of Major Repairs }\end{array}$ & 28 & 14 & 28 & 7 \\
\hline
\end{tabular}

With the exception of the Métis, Aboriginal people in Canada are much more likely to live in crowded housing conditions than are Non-Aboriginal Canadians (crowding is defined as more than one person per room) (Table 6). This is especially the case for the Inuit who are Io times more likely to live in crowded conditions. However, there has been some improvement over the I996-2006 decade. In I996, 36 per cent of Inuit, 7 per cent of Métis and 20 per cent of First Nations lived in crowded housing conditions. Crowding has been linked to a number of health outcomes, including increased risk of transmitting infectious diseases, severe lower respiratory tract infections, and higher rates of injuries, mental health problems, and family tensions $(62-64) \cdot 4$

The quality of housing is also a matter of concern. Inuit, Métis and First Nation people are from two to four times more likely to live in housing that requires major repairs, and the situation is deteriorating over time for the Inuit and First Nations. Ten years ago, in I996, the percentage of Inuit living in housing in need of major repairs stood at I9 per cent and First Nation at 26 per cent. For the Métis, there was a slight improvement over this decade.

\subsection{Employment and Income}

The literature is clear and convincing about the role of various dimensions of socio-economic status (SES) in determining health. Through colonization, colonialism, systemic racism and discrimination, Aboriginal peoples have been denied access to the resources and conditions necessary to maximize SES (22). This disadvantage is currently manifest in high rates of unemployment, scarce economic opportunities, poor housing, low literacy and educational attainment as well as meagre community resources (24).

With respect to poverty specifically, the most widely discussed impact of poverty is a lack of access to material resources, such as nutrient dense food, which leads to high rates of obesity and diabetes and resultant poor cardiovascular and renal health (80-85). Poverty is also linked to social exclusion, low social cohesion and increased crime (86). In the case of Aboriginal peoples, social exclusion in turn, prevents individuals from pursing education and training (87). More profound perhaps is the lack of control poverty creates, with resulting anxiety, insecurity, low self esteem and feelings of hopelessness (88-93). This and other forms of psychosocial stress have been linked to violence, addictions, poor parenting, and

4 "Crowding" is defined as more than one person per room. Not counted as rooms are bathrooms, halls, vestibules, and rooms used solely for business purposes. 
lack of social support. The accumulation of these psychosocial stressors often leads to poor mental health and increased vulnerability to infection, as well as diabetes, high blood pressure, and depression (94). In addition, suicide has been linked to poor mental health and substance abuse, which are in turn linked to social exclusion and poverty (95-96).

TABLE 7

Selected Labour Force ${ }^{5}$ Characteristics for the Aboriginal Identity Population ${ }^{6}$ in Canada, 15 Years and over, 2001 Census

\begin{tabular}{llllll}
\hline $\begin{array}{l}\text { Labour Force } \\
\text { Characteristic }\end{array}$ & $\begin{array}{l}\text { Total } \\
\text { Aboriginal }\end{array}$ & $\begin{array}{l}\text { North American } \\
\text { Indian }\end{array}$ & Métis & Inuit & $\begin{array}{l}\text { Total non- } \\
\text { Aboriginal }\end{array}$ \\
\hline Participation rate $^{7}$ & 61.4 & 57.3 & 69.1 & 62.5 & 66.5 \\
Employment rate $^{8}$ & 49.7 & 44.6 & 59.4 & 48.6 & 61.8 \\
Unemployment rate $^{9}$ & 19.1 & 22.2 & 14.0 & 22.2 & 7.1 \\
\hline
\end{tabular}

Table 7 shows significant inequalities in the participation of Aboriginal people in the economy. Aboriginal people are less likely than other Canadians to participate in the labour force (participation rate), and are even less likely to be employed (employment rate). If they are in the labour force, their level of unemployment is between two and three times higher than it is for other Canadians. Among Aboriginal people, North American Indians are the most disadvantaged.

TABLE 8

\section{Selected Income Characteristics of the Aboriginal Identity Population in Canada, 15 years of Age and over, 2001 Census}

\begin{tabular}{llllll}
\hline $\begin{array}{l}\text { Income } \\
\text { Characteristic }\end{array}$ & $\begin{array}{l}\text { Total } \\
\text { Aboriginal }\end{array}$ & $\begin{array}{l}\text { North } \\
\text { American } \\
\text { Indian }\end{array}$ & Métis & Inuit & $\begin{array}{l}\text { Total non- } \\
\text { Aboriginal }\end{array}$ \\
\hline $\begin{array}{l}\text { Average employment income } \\
\text { (full-time, full-year, in dollars) }\end{array}$ & 33,416 & 32,176 & 34,778 & 36,152 & 43,486 \\
$\begin{array}{l}\text { Average employment income } \\
\text { (part-time, part-year, in dollars) }\end{array}$ & 13,795 & 12,837 & 15,386 & 12,866 & 19,383 \\
$\begin{array}{l}\text { Government transfers as a } \\
\text { percentage of total income }\end{array}$ & 20.8 & 24.3 & 15.7 & 20.3 & 11.5 \\
$\begin{array}{l}\text { Median (total) income } \\
\begin{array}{l}\text { Incidence of low income in 2000 } \\
\text { (persons living in families, in \%) }\end{array}\end{array}$ & 31.2 & 12,263 & 16,342 & 13,699 & 22,431 \\
$\begin{array}{l}\text { Incidence of low income in 2000 } \\
\text { (unattached individuals, in \%) }\end{array}$ & 55.9 & 37.3 & 24.5 & 21.9 & 12.4 \\
\hline
\end{tabular}

\footnotetext{
Refers to those who are employed or unemployed

Does not include persons who gave more than one response with respect to Aboriginal identity.

Refers to those in the labour force expressed as a percentage of the total population I5 years and over.

Refers to those who are employed as a percentage of the population I5 years and over.

Refers to those who are unemployed expressed as a percentage of the labour force.
} 
We have established that Aboriginal people in Canada are less likely to be working. When they do find jobs, their annual earnings from employment are considerably lower than they are for other Canadians. This applies both when they work full-time, full-year and also when they work part-time or for a part of the year. Even sharper inequalities are evident when we look at total income received in the year. For North American Indians, for example, the median total income was $\$ 12,263$ in the year 2000, compared to almost twice that $(\$ 22,43 \mathrm{I})$ for other Canadians (Table 8). Because of high unemployment and low earnings, it is not surprising to see that income from government transfers, such as social assistance, is a much larger component of total income for Aboriginal persons than it is for other Canadians. ${ }^{\text {Io }}$

TABLE 9

Percentage of Those Reporting Fair or Poor Health by Household Income among Off-reserve Aboriginal and non-Aboriginal Peoples, Canada, 2000/01

\begin{tabular}{lll}
\hline Household Income Level & Aboriginal & Non-Aboriginal \\
\hline Low & $34 * 11$ & 25 \\
Middle & $26 *$ & 16 \\
High & $14 *$ & 9 \\
\hline
\end{tabular}

We have already suggested that income level has a bearing on health outcomes, and Table 9 confirms that the percentage of adults, both Aboriginal and non-Aboriginal, reporting that their health is only fair or poor declines substantially as one moves from lower to higher income levels. What the table also shows is that the gap in self-reported health is maintained at a statistically significant level (i.e. $\mathrm{p}=.05$ ) even when comparing individuals with the same or similar household income.

Of course there are many other determinants of health, such as education level, geographic location, employment status and so forth. Can the gap in health outcomes be explained if a large number of the known determinants were included in a multivariate analysis? The article from which the above table is drawn undertakes this kind of analysis and concludes that, depending on the health outcome introduced as the dependent variable, the gap is reduced but it does not go away. This unexplained residual, as it is called, suggests there must be "something else" out there that contributes to unequal health outcomes for Aboriginal people, something that has not yet been identified or satisfactorily measured. This lends some indirect support for the notion that the effects of historical trauma (e.g. lack of self-determination) may indeed be a determinant of health for Aboriginal populations.

Io Incidence of low income refers to the percentage of economic families or unattached individuals who spend $20 \%$ more than average on food, shelter and clothing.

II * indicates significantly different from the non-Aboriginal estimate. Percentages have been age standardized to the Canadian population. Contact Tjepkema for the exact figures which are not recorded on his chart. 
TABLE 10

Percentage of Those Experiencing a Major Depressive Episode in the Past Year by Household Income and Off-reserve Aboriginal Status, Canada, 2000/01

\begin{tabular}{lll}
\hline Household Income Level & Aboriginal & Non-Aboriginal \\
\hline Low Income & $21^{* 12}$ & 13 \\
Middle Income & $13^{*}$ & 9 \\
High Income & 7 & 6 \\
\hline
\end{tabular}

Often differences in health status observed between Aboriginal and non-Aboriginal populations can be explained by the fact that the two populations differ in other, health determining respects such as income and education. However, Table ro - while it only controls for one variable - suggests that there is more going on. When Aboriginal and nonAboriginal adults are compared at the same level of income, differences in the likelihood of experiencing a major depressive episode continue to be observed. It is only in the high income category that the difference is reduced to statistical insignificance $(p=.05) \cdot{ }^{\mathrm{I}}$

\subsection{Education}

Education, which is a component of SES, determines health through a number of avenues. By way of example, inadequate education often includes poor literacy, which affects ones ability to acquire information about proper nutrition or healthy food preparation. Insufficient education also diminishes the skills one might have to offer the labour market, often resulting in low paying jobs (97). The ensuing poverty and social exclusion, both disproportionately experienced by Aboriginal peoples, increases the risk of family instability, which often manifests in divorce and single parenthood (98).

There is clear evidence of inequities in the distribution of resources and opportunities to Aboriginal peoples in Canada (99). An example can be found in the area of education. Despite the growing number of Aboriginal peoples, particularly women, who are attaining post-secondary degrees, inadequate educational opportunities for most adults manifest as a lack of capacity to promote education among their children (IO०). An estimated 50\% of Aboriginal youth will drop out, or be pushed out, of high schools; resulting in diminished literacy and employment, as well as increased poverty in future generations (IOI).

\footnotetext{
I2 *indicates significantly different from the non-Aboriginal estimate. Percentages have been age standardized to the Canadian population. Contact Tjepkema for the exact figures which are not recorded on his chart.

I3 In the Canadian Community Health Survey, a major depressive episode is diagnosed on the basis of a series of questions that measure a cluster of symptoms for depressive disorders.

Household income is derived by calculating total annual income and taking into account the number of persons in the household.

Percentages have been age standardized to the Canadian population.

Two health regions have been excluded from the analysis.

* Significantly different from the non-Aboriginal estimate
} 
TABLE 11

Highest Level of Schooling Attained by the Aboriginal Identity Population in Canada, 15 years of age and over, 2001 Census

\begin{tabular}{llllll}
\hline $\begin{array}{l}\text { Highest Level of Schooling } \\
\text { Attained }\end{array}$ & $\begin{array}{l}\text { Total } \\
\text { Aboriginal }\end{array}$ & $\begin{array}{l}\text { North } \\
\text { American } \\
\text { Indian }\end{array}$ & Métis & Inuit & $\begin{array}{l}\text { Total non- } \\
\text { Aboriginal }\end{array}$ \\
\hline $\begin{array}{l}\text { Less than high school } \\
\text { graduation certificate }\end{array}$ & 48.0 & 50.6 & 42.2 & 57.7 & 30.1 \\
$\begin{array}{l}\text { High school graduation } \\
\text { certificate only }\end{array}$ & 9.9 & 9.0 & 11.9 & 6.2 & 14.2 \\
$\begin{array}{l}\text { Some postsecondary } \\
\text { education }\end{array}$ & 12.6 & 12.7 & 12.4 & 12.8 & 10.8 \\
$\begin{array}{l}\text { Trades certificate or diploma } \\
\text { College certificate or diploma }\end{array}$ & 12.1 & 11.5 & 13.6 & 11.1 & 10.8 \\
$\begin{array}{l}\text { University certificate or } \\
\text { diploma (below bachelor's) }\end{array}$ & 1.4 & 10.7 & 13.4 & 9.5 & 15.1 \\
\hline $\begin{array}{l}\text { Bachelor's degree } \\
\text { University certificate above }\end{array}$ & 3.4 & 1.4 & 1.4 & 0.8 & 2.6 \\
Bachelor's degree & 0.4 & 0.4 & 0.5 & 0.1 & 1.6 \\
\hline $\begin{array}{l}\text { Master's degree } \\
\text { Earned doctorate }\end{array}$ & 0.5 & 0.5 & 0.7 & 0.2 & 2.8 \\
\hline \begin{tabular}{l} 
TOTAL \\
\hline
\end{tabular} & 0.1 & 0.1 & 0.1 & 0.04 & 0.6 \\
\hline
\end{tabular}

Table II clearly shows how Aboriginal people are also disadvantaged when it comes to the level of education attained. The percentage of Aboriginal persons 15 years of age and over who have completed less than a high school education is in the order of 50 percent, compared to 30 per cent for other Canadians. Leaving school with less than high school education has been shown to significantly reduce the prospects of employment, income and other outcomes later in life, including health outcomes $(83,92)$.

The other side of the coin is the very limited representation of Aboriginal people at the higher end of the educational continuum, especially with respect to postsecondary certificates, diplomas and degrees. Within the Aboriginal population, the Inuit are the most disadvantaged in terms of educational achievement. 


\subsection{Food Insecurity ${ }^{14}$}

Poverty has clear outcomes on health because, in part, it determines what kinds of foods people have available to them and what they can afford to purchase. Thus, persons at lower incomes are subject to the stress of food insecurity from a compromised diet that results when food is no longer available.

TABLE 12

Prevalence of Food Insecurity, by Level and Selected Characteristics, Household Population, Canada Excluding Territories, 1998-99 (Percent)

\begin{tabular}{lll}
\hline Any Food Insecurity & Any Insecurity & Compromised Diet \\
\hline $\begin{array}{l}\text { Residents of households } \\
\text { relying on social assistance }\end{array}$ & 58 & 53 \\
Residents of low-income households & 35 & 30 \\
Lone mother with children & 32 & 28 \\
Aboriginal people off reserve & 27 & 24 \\
Children 0-17 & 14 & 11 \\
Total, Canada & 10 & 8 \\
\hline
\end{tabular}

In I998-99, Aboriginal people off reserve were almost three times more likely to be living in households experiencing food insecurity than was the case for all Canadians (27 percent to Io percent). Table I2 shows that this condition is strongly related to low incomes as well as single parent status, both of which we know from other data are more likely to occur in Aboriginal households. Thus, the result reported with respect to a high prevalence of food insecurity for Aboriginal people is not surprising. In the literature, food insecurity is related to health outcomes that include multiple chronic conditions, obesity, distress and depression. ${ }^{\mathrm{I}}$

So far, we have discussed proximal determinants of health as individual-level determinants - that is, particular characteristics of individuals such as poverty leading to particular individual-level health outcomes such as stress or obesity. Some work has been done, however, to aggregate individual level characteristics into community averages, and to construct community-level well-being scores.

I4 Food insecurity can refer to "any insecurity" that includes concern there will not be enough to eat because of a lack of money in the previous I2 months, as well as a "compromised diet," which includes either the quality or the quantity of food (or both) that one would want to eat because of a lack of money.

I5 (I) In the Canadian Community Health Survey, a major depressive episode is diagnosed on the basis of a series of questions that measure a cluster of symptoms for depressive disorders.

(2) Household income is derived by calculating total annual income and taking into account the number of persons in the household.

(3) Percentages have been age standardized to the Canadian population.

(4) Two health regions have been excluded from the analysis.

(5) * Significantly different from the non-Aboriginal estimate. 


\subsection{Intermediate Determinants of Health}

While proximal determinants represent the root of much ill health among Aboriginal peoples, intermediate determinants can be thought of as the origin of those proximal determinants. For instance, poverty and deleterious physical environments are rooted in a lack of community infrastructure, resources and capacities, as well as restricted environmental stewardship. Likewise, inequitable health care and educational systems often act as barriers to accessing or developing health promoting behaviours, resources and opportunities. The interaction of intermediate determinants is especially evident in the connection between cultural continuity and other intermediate determinants, all of which have a direct influence on proximal determinants.

\subsection{Health Care Systems}

In order to realize the benefits of an advanced system of health care, Canadian individuals must have physical, political and social access to those services; this is often not the case for Aboriginal peoples (IO2-IO3). The federal system of health care delivery for status First Nations people resembles a collage of public health programs with limited accountability, fragmented delivery and jurisdictional ambiguity (IO4-I05). Moreover, current health care services remain focused on communicable disease, while mortality and morbidity among Aboriginal peoples are increasingly resulting from chronic illness. Social access to health care is similarly limited or denied to Aboriginal peoples through health systems that account for neither culture nor language, or the social and economic determinants of Aboriginal peoples' health (IO6-IO9).

TABLE 13

Health Care Utilization and Access, Household Population Aged 15 or Older, by Off-reserve Aboriginal Status, Canada and the Northern Territories, 2000-01 ${ }^{16}$

\begin{tabular}{|c|c|c|c|c|}
\hline Utilization and Access & Canada & & Territories & \\
\hline $\begin{array}{l}\text { Contact with health professional } \\
\text { in last } 12 \text { months }\end{array}$ & Aboriginal & $\begin{array}{l}\text { Non- } \\
\text { Aboriginal }\end{array}$ & Aboriginal & $\begin{array}{l}\text { Non- } \\
\text { Aboriginal }\end{array}$ \\
\hline General practitioner & 76.8 & 78.7 & $58.8 *$ & $75 \cdot 9$ \\
\hline Eye specialist & 37.9 & 38.0 & $35 \cdot 3$ & 39.1 \\
\hline Other medical doctor & $24.7^{*}$ & 28.9 & $15.1^{*}$ & 24.1 \\
\hline Nurse & $16.8 *$ & 9.8 & $49.0 *$ & 22.0 \\
\hline Dentist & $45.2 *$ & 59.4 & $45.0 *$ & $53 \cdot 5$ \\
\hline Has a regular doctor & $76.4^{*}$ & 83.9 & $31.1^{*}$ & 67.0 \\
\hline Unmet health care needs & $19.6 *$ & 12.7 & 18.4 & 13.6 \\
\hline
\end{tabular}

i6 * Significantly different from the non-Aboriginal estimate 
Another determinant of positive health outcomes is having access to the required services on a timely basis. Table $\mathrm{I} 3$ shows different patterns of utilization of health care professionals, and suggests more limited access to doctors and dentists. This is most notable in the North, where nurses play a stronger role. Also, a higher percentage of Aboriginal people indicate that they have unmet health care needs. ${ }^{\mathrm{I} 7}$

TABLE 14

Barriers to Accessing Health Services, First Nation Adults Living On Reserve, 2002-0318

Access Barrier

(1) Systemic barriers

Waiting list too long

Not covered by NIHB

NIHB approval denied

Unable to arrange transport

(2) Barriers related to First Nation specific needs

Felt Health care provided was inadequate

Service not culturally appropriate

Difficulty getting traditional care

Chose not to see health professional

(3) Barriers related to geography and the availability of services

Doctor or nurse not available in my area

Service was not available in my area

Health facility not available

(4) Economic factors

Could not afford transportation costs

Could not afford direct cost of care, service

Could not afford child care costs
18.5

First Nation Adults On Reserve
33.2

20.0

16.1

$14 \cdot 5$
$13 \cdot 5$

13.4

10.9

14.7

10.8

As with other Canadians, First Nation adults living on reserve have difficulty accessing health care services because of long wait lists (Table I4). In addition, however, they are limited by needed services not being covered or approved by the federal Non-Insured Health Benefit plan and by doctors or nurses not being available in their area. Feeling that the health care provided was inadequate or not culturally appropriate were also barriers that were frequently mentioned. The fact that many First Nation adults live in rural and more isolated communities, and at very low levels of income, led to a number of economic barriers to accessing health care.

I7 * Significantly different from the non-Aboriginal estimate

I8 Data from the Regional Health Survey is only available for First Nation persons living on reserve. Equivalent information for Metis and Inuit is not available. 


\subsection{Educational Systems}

Adequate education, which in many ways continues to be denied to Aboriginal peoples, has a profound impact on income, employment and living conditions. Well-educated parents not only earn higher incomes, thereby improving proximal determinants of health, but they also pass the value of education and life-long learning to the next generation (IIO-III). Preschool programs have demonstrated the most favourable "return on investment" among Aboriginal children (II2). In fact, not only has education been correlated with optimal child development, but it has also been shown to mitigate some of the effects of poor child development on adult health (II3). Yet, programs such as Aboriginal Head Start continue to be under-funded (27). Similarly, although the benefits of "culturally competent" curricula have been demonstrated to retain Aboriginal high school students, most curricula continue to lack any focus on Indigenous content or learning styles (II4). Finally, mainstream education systems pay little attention to social determinants that might act as obstacles for Aboriginal children and youth realizing the most from their education.

\subsection{Community Infrastructure, Resources and Capacities:}

The health of an individual and their family is substantially influenced by the community in which they live. In the case of Aboriginal peoples, the Assembly of First Nations and others contend that economic development is a key determinant of health (II5-II8). Limited infrastructure and resource development opportunities have been important contributors to economic insecurity and marginalization, with subsequent deprivation among community members. In addition, inadequate social resources, in the form of qualified individuals who can develop and/or implement programs, restrict Aboriginal communities' access to funding. When communities experience fragmented, under-funded programs in which the bureaucracy increases community responsibility without a concomitant increase in power, community-level stress and paralysis can result (II9).

\subsection{Environmental Stewardship}

Another key intermediate determinant of health that has been widely recognized is environmental stewardship (I). In fact, traditional ties to the natural environment are generally acknowledged as a major resource for the superior health enjoyed by Indigenous peoples prior to European colonization of the Americas (I20). Unfortunately, the past 500 years have witnessed a rapid transition from a healthy relationship with the natural world to one of dispossession and disempowerment. Aboriginal peoples are no longer stewards of their traditional territories, nor are they permitted to share in the profits from the extraction and manipulation of natural resources. Finally, contamination of wildlife, fish, vegetation and water have forced Aboriginal peoples further from the natural environments that once sustained community health (I20). 
TABLE 15

\section{Connection to the Land}

\begin{tabular}{ll}
\hline Connection to the Land & Per cent \\
\hline $\begin{array}{l}\text { Per cent of adult respondents reporting on progress in renewing } \\
\text { the relationship of First Nation persons to the land: }\end{array}$ \\
$\quad$ Good progress & 11.1 \\
$\quad$ No progress & 45.5 \\
Per cent of adults reporting that they often consume & \\
traditional foods & 59.3 \\
$\quad$ Protein-based foods such as game, fish & 21.8 \\
$\quad$ Berries and other types of vegetation & 42.2 \\
\hline
\end{tabular}

The Regional Health Survey reveals that a high proportion of First Nation adults are still tied to the land when it comes to food sources, but very few believe that there has been much progress made in their community in renewing their relationship to the land (Table I5).

\subsection{Cultural Continuity}

A landmark study conducted by Chandler and Lalonde (I998) revealed that among First Nations people in British Columbia, rates of suicide (which are strongly linked to proximal determinants) varied dramatically and were associated with a constellation of characteristics referred to as "cultural continuity" (I2I). Cultural continuity might best be described as the degree of social and cultural cohesion within a community. According to Chandler and Lalonde, low rates or an absence of suicide in a community appear to be related to: land title, self-government (particularly the involvement of women), control of education, security and cultural facilities, as well as control of the policies and practice of health and social programs. Cultural continuity also involves traditional intergenerational connectedness, which is maintained through intact families and the engagement of elders, who pass traditions to subsequent generations (I2I). 
TABLE 16

Percentage of First Nations People Who Have Knowledge of an Aboriginal Language, by Age Groups, Canada 2001 and 2006

\begin{tabular}{|c|c|c|c|c|c|c|}
\hline Age Groups & $\begin{array}{l}\text { Total } \\
2001\end{array}$ & $\begin{array}{l}\text { On Reserve } \\
2001\end{array}$ & $\begin{array}{l}\text { Off Reserve } \\
2001\end{array}$ & $\begin{array}{l}\text { Total } \\
2006\end{array}$ & $\begin{array}{l}\text { On Reserve } \\
2006\end{array}$ & $\begin{array}{l}\text { Off Reserve } \\
2006\end{array}$ \\
\hline Total all ages & 30 & 50 & 14 & 29 & 51 & 12 \\
\hline o to 14 years & 21 & 36 & 8 & 21 & 39 & 6 \\
\hline 15 to 24 years & 25 & 44 & 10 & 24 & 43 & 9 \\
\hline 25 to 44 years & 33 & 58 & 17 & 30 & 56 & 13 \\
\hline 45 to 64 years & 45 & 71 & 26 & 39 & 67 & 21 \\
\hline 65 to 74 years & 56 & 79 & 33 & 50 & 79 & 26 \\
\hline $\begin{array}{l}75 \text { years and } \\
\text { over }\end{array}$ & 59 & 83 & 31 & 52 & 83 & 24 \\
\hline
\end{tabular}

Overall, it appears that the percentage of First Nation persons claiming knowledge of an Aboriginal language is holding steady at about 30 per cent (Table I6), but this masks some slight gains for the on reserve population and some losses on the part of those living off reserve. There is cause for concern both because the off reserve percentages are so low and because the younger age groups are much less likely to report knowing an Aboriginal language compared to those in the older age groups. (See Appendices - Tables 29 \& 30).

TABLE 17

Percentage of Inuit Population who Reported Inuktitut as Mother Tongue and as Home Language ${ }^{19}$, and Knowledge ${ }^{20}$ of Inuktitut, Canada and Regions, 1996 and 2006

\begin{tabular}{lllllll}
\hline Regions & $\begin{array}{l}\text { Inuktitut } \\
\text { mother } \\
\text { tongue, } \\
1996\end{array}$ & $\begin{array}{l}\text { Inuktitut } \\
\text { mother } \\
\text { tongue, } \\
2006\end{array}$ & $\begin{array}{l}\text { Inuktitut } \\
\text { home } \\
\text { language, } \\
1996\end{array}$ & $\begin{array}{l}\text { Inuktitut } \\
\text { home } \\
\text { language, } \\
2006\end{array}$ & $\begin{array}{l}\text { Knowledge } \\
\text { of Inuktitut, } \\
1996\end{array}$ & $\begin{array}{l}\text { Knowledge } \\
\text { of Inuktitut } \\
2006\end{array}$ \\
\hline Canada & 68 & 64 & 58 & 50 & 72 & 69 \\
$\begin{array}{l}\text { Total, Inuit } \\
\text { Nunaat }\end{array}$ & 79 & 78 & 69 & 63 & 84 & 84 \\
$\begin{array}{l}\text { Total, Outside } \\
\text { Inuit Nunaat }\end{array}$ & 13 & 14 & 4 & 4 & 16 & 15 \\
\hline
\end{tabular}

Use of the Inuktitut language by the Inuit is quite high, especially in Inuit Nunaat or homeland territories such as Nunavik and Nunavut where it approaches roo per cent (Table I7). However, comparisons between I996 and a decade later suggest that the use of the language is declining.

\footnotetext{
I9 "Mother tongue" refers to the first language learned at home in childhood and still understood. "Home language" refers to the language spoken most often at home.

20 "Knowledge" refers to languages in which the respondent can conduct a conversation.
} 
TABLE 18

Percentage of the Métis Population with Knowledge of an Aboriginal Language, by Age Groups, Canada, 2006

\begin{tabular}{lc}
\hline Age Group & Knowledge of an Aboriginal language(per cent) \\
\hline 14 years and under & 2 \\
15 to 24 years & 2 \\
25 to 44 years & 3 \\
45 to 64 years & 6 \\
65 to 74 years & 9 \\
75 years and over & 12 \\
\hline
\end{tabular}

In contrast to the Inuit and First Nation populations, the percentage of Métis with knowledge of an Aboriginal language is quite low, and this is especially the case for those in the younger age groups (Table I8). We know from other results that Cree is the most common language of the Métis, followed by Dene and Ojibway. Very few speak Michif, the traditional language of the Métis, which involves a mixture of the Cree and French languages.

TABLE 19

Percentage of First Nation Adults Living on Reserve Who Consider Traditional Spirituality and Religion Important in Their Lives

\begin{tabular}{lc}
\hline Indicator & First Nation Adults Living on Reserve \\
\hline $\begin{array}{l}\text { Traditional spirituality is very or somewhat important } \\
\text { in my life }\end{array}$ & 76.4 \\
Religion is very or somewhat important in my life & 70.3 \\
\hline
\end{tabular}

According to the Regional Health Survey, close to three-quarters of First Nation adults living on reserve consider traditional spirituality and religion to be very or somewhat important in their lives (Table I9).

\subsection{Distal Determinants of Health}

Distal determinants have the most profound influence on the health of populations because they represent political, economic, and social contexts that construct both intermediate and proximal determinants. In the case of Aboriginal peoples, although intra and inter-group differences exist (I22), to a large extent, colonialism, racism and social exclusion, as well as repression of self-determination, act as the distal determinants within which all other determinants are constructed. Historical research clearly indicates a link between the social inequalities created by colonialism and the disease, disability, violence and early death experienced by Aboriginal peoples in Canada (I23). 
According to Kelm (I998), "colonization is a process that includes geographic incursion, socio-cultural dislocation, the establishment of external political control and economic dispossession, the provision of low-level social services and ultimately, the creation of ideological formulations around race and skin colour that position the colonizer at a higher evolution level than the colonized" (I23). While neo-colonialism detrimentally influences the health of contemporary Aboriginal peoples, historic, successively traumatic events continue to affect generations through what has been referred to as 'historic or cultural trauma' (I24). In essence, the collective burden of a repressive colonial system has created conditions of physical, psychological, economic and political disadvantage for Aboriginal peoples.

\subsection{Colonialism:}

Colonialism impacts the health of Aboriginal peoples by producing social, political and economic inequalities that 'trickle down' through the construction of unfavourable intermediate and proximal determinants (I24). The specific mechanisms of colonialism occur in diverse domains such as environmental relationships, social policies and political power.

The impact of colonialism on Aboriginal peoples' relationship with the environment began with their dispossession of and displacement from traditional lands in the 2oth century. Essentially, people were restricted from or forbidden to hunt, trap or fish for the purpose of subsistence. Several Indigenous authors contend that the historic trauma experienced by many Aboriginal peoples is rooted in this dislocation from the land (4). In support of this, researchers have discovered that traditional harvesting is linked to a greater rapport with the land, an increased sense of self-reliance and enhanced overall health (22).

The political agenda of the 2 oth century colonial system was to assimilate and acculturate Indigenous peoples into the dominant culture. This agenda is evident in legislation and social policies that reward assimilation through resources and opportunities, while punishing cultural retention through the creation of inequities (22).

Perhaps the most powerful mechanism of assimilation was the residential schools, which are often considered the vanguard of genocide and re-socialization of Aboriginal peoples (I25-I26). Through these schools, culture, language, family ties and community networks were destroyed for generations of First Nations, Métis and Inuit children. The result has been dramatic and devastating socio-cultural change among all Aboriginal peoples, including disengagement by many from their ancestry and culture. 
TABLE 20

The Impact of Residential Schools on First Nation Adults Living on Reserve, 2002-03

\begin{tabular}{ll}
\hline Residential School Characteristics & Per cent \\
\hline $\begin{array}{l}\text { Proportion of adults attending } \\
\begin{array}{l}\text { Proportion of those attending reporting a negative impact on } \\
\text { their overall health and well-being }\end{array}\end{array}$ & 20.3 \\
$\begin{array}{l}\text { Belief that parent's attendance at residential schools negatively } \\
\text { affected the parenting they received as children }\end{array}$ & 47.3 \\
$\begin{array}{l}\text { Most frequently mentioned elements of the residential school experience that } \\
\text { contributed to the negative impact on health and well-being of survivors: }\end{array}$ & 43.0 \\
$\quad$ Isolation from family & \\
Verbal or emotional abuse & 81.3 \\
Harsh discipline & 79.3 \\
\hline Loss of cultural identity & 78.0 \\
\hline Separation from First Nation or Inuit community & 76.8 \\
Witnessing abuse & 74.3 \\
Loss of language & 71.5 \\
\hline Physical abuse & 71.1 \\
\hline
\end{tabular}

One major dimension of historical trauma is the experience that Aboriginal students went through in attending residential schools, an experience that still has ramifications today for the health and well-being not only of the survivors, but also their children and grandchildren. Of the adults interviewed by the First Nations Regional Longitudinal Health Survey, 20 per cent are survivors of residential schools, a figure that jumps to almost 50 per cent for those who are in the above 50 age bracket. Almost half of the survivors report that the experience negatively affected their health and well-being. Table 20 also reveals that 43 per cent of their children believe the residential school experience of their parents had a negative effect on the parenting skills of their parents. Specific aspects of the residential school experience are identified as contributing to the negative impact on the health and wellbeing of the survivors. (See Appendices - Tables 3I \& 32).

\subsection{Racism and Social Exclusion:}

Racism and social exclusion have been a reality for Aboriginal peoples since first contact with British colonizers. The colonial system created social stratification along ethnic lines, with a consequent hierarchical distribution of resources, power, freedom and control, all of which ultimately influenced Aboriginal health (I27). Education, income and economy are driven by social policies, making the inequitable distribution of these determinants a social justice issue for Aboriginal peoples (I28-I29). Racism and its subsequent social exclusion continue to create barriers to Aboriginal participation and productivity in the national economy (22). Without equitable distribution of the determinants of health, Aboriginal peoples cannot 
realize the same possibilities for health. Relegated to the bottom of the social hierarchy, Aboriginal peoples continue to be exposed to health damaging intermediate and proximal determinants, which increase their vulnerability to illness and reduce their capacity to address ill health.

TABLE 21

Instances of Racism Experienced by First Nation Adults on Reserve and Perceived Impact on Level of Self-Esteem, 2002-03

\begin{tabular}{ll}
\hline Racism and its Effects & Per cent \\
\hline $\begin{array}{l}\text { Per cent of adult respondents reporting having experienced instances of racism in the } 12 \\
\text { months prior to the survey }\end{array}$ & 37.9 \\
\hline $\begin{array}{l}\text { Perceived impact of experiences with racism on respondent's level of self-esteem } \\
\text { No effect }\end{array}$ & 48.4 \\
Little effect & 22.6 \\
Some effect & 18.9 \\
\hline Strong effect & 8.1 \\
\hline
\end{tabular}

Research is now establishing that groups that are subject to racial and other forms of discrimination may well have more negative health outcomes because of the stress of living in a racially charged environment (85). While the level of racism affecting particular groups is difficult to measure, one approach is to ask respondents if they have experienced racism within a given time period. In response to such a question, almost 40 per cent of First Nation adults living on reserve say that they have experienced racism in the I2 months prior to the survey (Table 2I). When Aboriginal youth experience social exclusion, research indicates that alcohol and drug use increases (I3O-I3I). Furthermore, 27 per cent of those who experienced racism say that it had some, or a strong, effect on their level of self-esteem. ${ }^{2 \mathrm{I}}$

\subsection{Self-Determination:}

Self-determination has been cited as the most important determinant of health among Aboriginal peoples (I32-I33). Self-determination influences all other determinants including education, housing, safety, and health opportunities. Recently, Chandler and Lalonde provided evidence of this link through an inverse relationship between self-determination and suicide among First Nations in British Columbia (I2I).

In order to ensure the most favourable intermediate determinants of health, Aboriginal peoples must participate equally in political decision-making, as well as possess control over their lands, economies, education systems, and social and health services. Unfortunately, this is not the case; rather, the colonial agenda has enforced unequal access

2I Data on impact on self-esteem is from Nova Scotia only since national data is unpublished. The national data will be substituted in due course. 
to and control over property, economic assets and health services. In many ways, this restrictive structure has actually encouraged Aboriginal social, political and economic development that is not self-determined.

Equity requires authority and freedom, with authority involving material, psychosocial and political domains. Unfortunately, colonial governments and institutions do not act upon evidence, resulting in unequal participation of Aboriginal people in political institutions that govern their fate.

TABLE 22

Self-determination Indicators by Feelings of Depression and Sadness for First Nation Adults Living on Reserve, 2002-03

\begin{tabular}{lcc}
\hline Per cent who strongly agree that: & Depressed & Not depressed \\
\hline I can solve the problems that I have & 32.4 & 38.5 \\
\hline No one pushes me around in life & 33.8 & 41.0 \\
\hline I have control over things that happen to me & 28.0 & 31.1 \\
I can do just about anything I set my mind to & 35.2 & 43.2 \\
\hline I often feel helpless in dealing with the problems of life & 7.4 & 4.1 \\
What happens to me in the future mostly depends on me & 37.0 & 37.6 \\
\hline There's little I can do to change many of the important things in my life & 10.6 & 5.9 \\
\hline
\end{tabular}

Some research has traced a link between self-determination at the community level and health outcomes. It appears that there is also a connection at the individual level, between the degree to which persons believe that they are in control of their lives on the one hand, and feelings of depression on the other (Table 22). (See Appendices - Tables $27 \& 28$ ).

\subsection{Conclusion}

Data presented in this paper clearly demonstrate the burdensome health disparities facing all Aboriginal peoples. Yet, these disparities are not homogenous and must be understood within the diverse and sometimes disparate contexts within which First Nations, Inuit and Metis people live. Beyond health behaviours, the evidence is clear that social determinants at proximal, intermediate and distal levels influence health in complex and dynamic ways. The individual and cumulative effects of inequitable social determinants of health are evident in diminished physical, mental, and emotional health experienced by many Aboriginal peoples. Unfavourable distal, intermediate and proximal determinants of health are associated with increased stress though lack of control, diminished immunity and resiliency to disease and social problems, as well as decreased capacity to address ill health. The complex interaction between various determinants appears to create a trajectory of health for individuals that must be addressed through a social determinants approach. 
It is clear that the origin of good health arises long before conception, with the historical, political, economic and social contexts into which we are born. After birth, distal, intermediate and proximal determinants continue to influence health over the life span. Beginning in early childhood, social determinants establish a potential trajectory that is only moderately mutable in the current social and economic context within which many Aboriginal children live. Access to resources for health during this critical developmental stage has implications over the entire life course, particularly for adult health. In fact, Marmot (I3) suggests that, "the seeds of adult health and health inequity are sown in early childhood" (pg I9). For example, children require a healthy environment in order to maximize brain development and the ability to learn and experience themselves and the world. Less than optimal development has consequences not just for adult health, but also for the health of subsequent generations through the environments created by physically, emotionally, mentally, or spiritually unhealthy adults. Aboriginal peoples are the fastest growing demographic group in Canada, with almost $60 \%$ of the Aboriginal population under the age of 25 (134). The health consequences of unhealthy developmental environments for this fast-growing population of children and youth are obvious, considerable, compounding and potentially devastating.

\subsection{Putting It Together: The Integrated Life Course and Social Determinants Model of Aboriginal Health (ILCSDAH)}

The complex, intersecting and interrelated determinants and contexts of Aboriginal health requires a model that permits researchers to explore the pathways that influence health and the points at which interventions will be more effective. The "Integrated Life Course and Social Determinants Model of Aboriginal Health" depicts life stages, socio-political contexts and social determinants as nested spheres of origin, influence and impact; each affecting the other in temporally and contextually dynamic and integrated ways. The model incorporates four dimensions of health across the life course including, physical, spiritual, emotional and mental. This multi-dimensional construct reflects Aboriginal contexts and social determinants that not only have a direct impact on health but also interact with one another to create vulnerabilities and capacities for health.

The ILCSDAH-Model permits not only examination of the distal, intermediate and proximal social determinants of health, but also accounts for the unique sociopolitical contexts, life stages and dimensions of health that act as pathways through which determinants express influence. This model encourages examination of the ways in which socio-political contexts and life stages are shaped by and, in turn shape, social determinants of all domains of health.

The model also permits an analysis of how the differential health impacts of social determinants on children, youth and adults is filtered through diverse Aboriginal sociopolitical contexts, within and across Inuit, Métis and First Nations communities (including 
urban, rural, settlement and reserve). Socio-political contexts not only represent filters through which social determinants influence health, they also represent barriers and opportunities for addressing children, youth and adult health.

The ILCSDAH model conceptualizes the origin and influence of social determinants within distal, intermediate and proximal domains. This classification is based on Marmot's 2007 reference to the "causes of causes" of health (13). Proximal, intermediate and distal social determinants are filtered through socio-political contexts, life stages and health dimensions (physical, emotional, mental and spiritual) to shape overall well-being. The sphere reflects not only the multi-dimensionality of each domain of health and its social determinants, but also the interrelatedness of these domains. Although the model adds additional layers of abstraction to current Aboriginal health models, it also reflects the reality of what is now clearly understood as a complex and dynamic interplay of social, political, historical, cultural, environmental, economic and other forces that directly and indirectly shape Aboriginal health.

A particular advantage of this model is that it permits an exploration of potential trajectories of health influence across the life course. The notion of health trajectories not only corresponds with many Indigenous ideologies, which employ temporal concepts to understanding health, but might also facilitate prediction of the ways socially determined health vulnerabilities among children and youth are predictive of health problems during adulthood. Ultimately, assessment of social determinants could lead to individual, family and/or community interventions that improve health outcomes.

\section{Integrated Life Course and Social Determinants Model of Aboriginal Health}
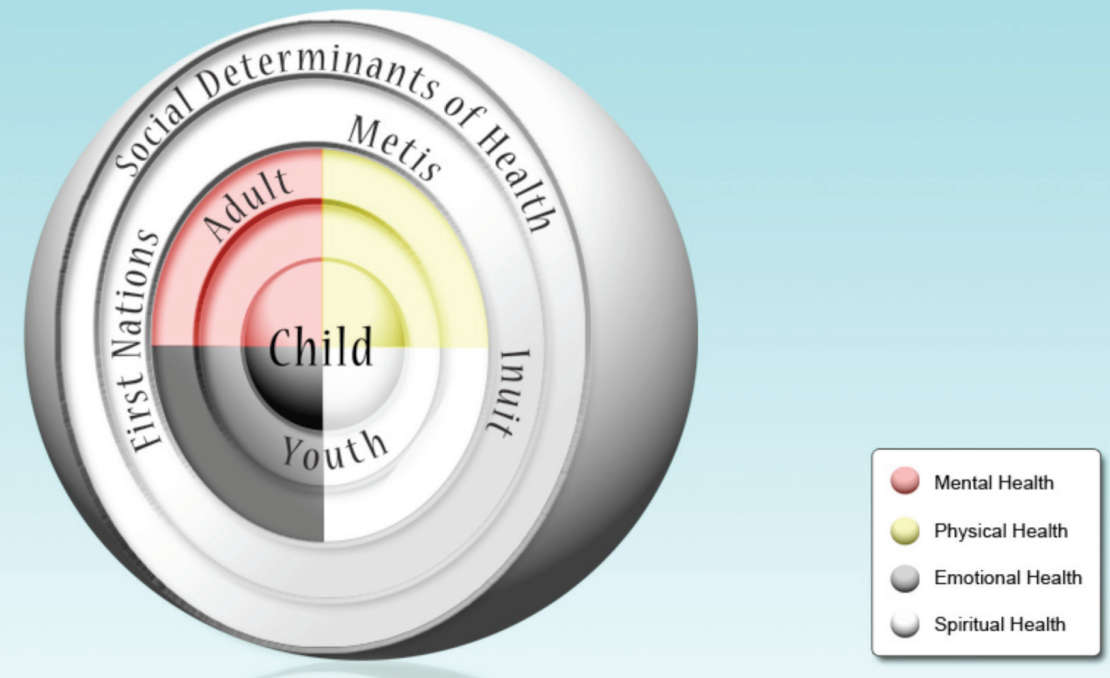


\section{APPENDICES}

TABLE 23

Most Frequent Long-Term Health Related Conditions among First Nations Children Living On Reserve, 2002-03

\begin{tabular}{lc}
\hline Long-term condition & Per cent of First Nation Children On Reserve \\
\hline Asthma & 14.6 \\
Allergies & 12.2 \\
Chronic ear infections or ear problems & 9.2 \\
Chronic bronchitis & 3.6 \\
Learning disability & 2.9 \\
\hline
\end{tabular}

First Nation children living on reserve encounter a number of chronic or long-term health conditions that are often triggered by foreign substances in the environment, such as tobacco smoke, smog and mould. The most common conditions are asthma, allergies, ear infections and bronchitis. Typically, the prevalence of these conditions is higher for First Nation children than it is for all Canadian children (for example, asthma and bronchitis). The prevalence of learning difficulties is also a source of concern.

\section{Source:}

First Nations Regional Longitudinal Health Survey (RHS) 2002/03: Results for Adults, Youth and Children Living in First Nations Communities, Ottawa: First Nations Centre, National Aboriginal Health Organization, 2005, p. 268, 269.

TABLE 24

Most Frequent Long-Term Health Related Conditions among First Nation Youth Living On Reserve, 2002-03

\begin{tabular}{lc}
\hline Long-term condition & Per cent of First Nation youth on reserve \\
\hline Allergies & 15.1 \\
Asthma & 13.6 \\
Chronic ear infections or ear problems & 4.8 \\
Learning disability & 3.5 \\
Chronic bronchitis & 2.4 \\
\hline
\end{tabular}

Although the percentages and rankings differ slightly, we note that the most frequently occurring long-term health conditions experienced by First Nation youth living on reserve are the same as those for children.

\section{Source:}

First Nations Regional Longitudinal Health Survey (RHS) 2002/03: Results for Adults, Youth and Children Living in First Nations Communities, Ottawa: First Nations Centre, National Aboriginal Health Organization, 2005, p. I79 
TABLE 25

Frequently-Occurring Long-term Health Conditions of First Nation Adults Living on Reserve, and Other Adults in Canada

\begin{tabular}{llllll}
\hline $\begin{array}{l}\text { Long-term } \\
\text { health conditions }\end{array}$ & $\begin{array}{l}\text { First Nation } \\
\text { adults } \\
\text { on reserve }\end{array}$ & $\begin{array}{l}\text { N.A. Indian } \\
\text { off reserve }\end{array}$ & Métis & Inuit & $\begin{array}{l}\text { Other } \\
\text { Canadian } \\
\text { adults }\end{array}$ \\
\hline Arthritis or rheumatism & 25.3 & 20.3 & 19.5 & 9.4 & 19.1 \\
High blood pressure & 20.4 & 12.0 & 12.7 & 8.1 & 16.4 \\
Allergies & 19.9 & $\mathrm{n} / \mathrm{a}$ & $\mathrm{n} / \mathrm{a}$ & $\mathrm{n} / \mathrm{a}$ & 30.3 \\
Diabetes & 19.7 & 8.3 & 5.9 & 2.3 & 5.2 \\
Chronic back pain & 16.7 & $\mathrm{n} / \mathrm{a}$ & $\mathrm{n} / \mathrm{a}$ & $\mathrm{n} / \mathrm{a}$ & 21.4 \\
\hline
\end{tabular}

The long-term health conditions that affect First Nation adults living on reserve tend to be the same as those affecting other Canadians except that diabetes is much more important in the First Nation population. The data also suggest that Aboriginal people living off reserve tend to have lower prevalence of long-term conditions than do those living on reserve, and this is especially the case for diabetes, but these rates are still typically higher than they are for other Canadian adults except in the case of the Inuit. ${ }^{22}$

TABLE 26

Body Mass Index, Household Population 15 years of Age and Over, by Off-reserve Aboriginal Status, Canada, 2000/01

\begin{tabular}{lll}
\hline Body Mass Index & Aboriginal Off Reserve & Non-Aboriginal \\
\hline Acceptable or underweight & 41.8 & 54.3 \\
Overweight & 33.5 & 31.7 \\
Obese & 24.7 & 14.0 \\
\hline
\end{tabular}

Aboriginal adults living off reserve are much more likely to be obese than is the case for Non-Aboriginal adults in Canada. Other data available to us suggests that this difference is even stronger for First Nation adults living on reserve where obesity levels are in the range of 36 per cent, but methods of calculation are not strictly comparable.

\section{Technical Notes}

(I) Body Mass Index (BMI) was calculated by dividing weight in kilograms by the square if height in metres. Three weight categories were identified: Acceptable or underweight (BMI less than 25), overweight (BMI 25 to less than 30), and obese (BMI of 30 or more).

(2) Percentages have been age-standardized to the total Canadian population.

22 The Aboriginal Peoples Survey defines adults as those I5 years of age and over. In the Regional Health Survey, adults are considered to be 18 years of age and over. 
Source:

2000/OI Canadian Community Health Survey as reported in Michael Tjepkema, "The Health of the Off-reserve Aboriginal Population", Health Reports, Volume 13, 2002, supplement.

Ottawa: Statistics Canada, Catalogue 82-003, Table 2, p.8

TABLE 27

Adults 15 years of Age and Over Who Have Suffered a Major Depressive Episode in the Last 12 Months by Off-Reserve Aboriginal Status (Percent)

\begin{tabular}{lll}
\hline Mental Health Indicator & Aboriginal Off-Reserve & Non-Aboriginal \\
\hline $\begin{array}{l}\text { Suffered a major depressive } \\
\text { episode in past } 12 \text { months }\end{array}$ & $13.2 *$ & 7.3 \\
\hline
\end{tabular}

In the Canadian Community Health Survey, a major depressive episode is diagnosed on the basis of a series of questions that measure a cluster of symptoms for depressive disorders. Aboriginal adults living off-reserve are almost twice as likely to experience a major depressive disorder compared to other Canadians. ${ }^{23}$

TABLE 28

Percentage of First Nation Youth Living on Reserve who Report Feeling Sad, Blue or Depressed for Two Weeks or More in a Row

\begin{tabular}{lll}
\hline Mental Health Indicator & Female Youth & Male Youth \\
\hline Feeling sad, blue or depressed for 2 weeks or more & 37.1 & 18.1 \\
\hline
\end{tabular}

A high percentage of First Nation youth living on reserve report feeling sad, blue or depressed for two weeks or more in the previous year. Table 28 also reveals a substantial difference between male and female youth.

\section{Source:}

First Nations Regional Longitudinal Health Survey (RHS) 2002/03: Results for Adults, Youth and Children Living in First Nations Communities, Ottawa: First Nations Centre, National Aboriginal Health Organization, 2005, p. 22 I.

23 Significantly different from the non-Aboriginal estimate. 
TABLE 29

Importance of Keeping, Learning or Relearning an Aboriginal Language, by Age Group, Métis Identity Non-reserve Population 15 years of Age and Over, 2001

\begin{tabular}{lllll}
\hline $\begin{array}{l}\text { Age } \\
\text { Group }\end{array}$ & $\begin{array}{l}\text { Very or somewhat } \\
\text { important }\end{array}$ & $\begin{array}{l}\text { Not very or Not } \\
\text { important }\end{array}$ & $\begin{array}{l}\text { No } \\
\text { opinion }\end{array}$ & $\begin{array}{l}\text { Not stated, } \\
\text { refused }\end{array}$ \\
\hline Aged 15+ & 49.6 & 46.4 & 1.9 & 1.9 \\
\hline 15-24 years & 47.0 & 48.7 & 2.2 & 1.9 \\
25-44 years & 52.9 & 43.4 & 1.7 & 1.8 \\
45-64 years & 47.9 & 48.4 & 1.4 & 2.0 \\
65 and over & 42.6 & 51.5 & 3.6 & 2.2 \\
\hline
\end{tabular}

Aboriginal groups typically place a high value on the importance of retaining, learning or relearning their Aboriginal language, and the Métis are not an exception. In this chart, we learn that approximately half the adult Métis population believes that this issue is either very or somewhat important, and the opinions are fairly consistent across different age groups.

\section{Source:}

Aboriginal Data Samples for Regional Discussions, Ottawa: Statistics Canada, February/March 2007, page 9 .

TABLE 30

Who Helps Aboriginal Children Learn an Aboriginal Language (Canada, 2001)

\begin{tabular}{lllll}
\hline $\begin{array}{l}\text { Type of person assisting with } \\
\text { language instruction }\end{array}$ & Inuit & $\begin{array}{l}\text { North American } \\
\text { Indian Off-reserve }\end{array}$ & $\begin{array}{l}\text { First Nation On } \\
\text { Reserve }\end{array}$ & Métis \\
\hline Parents & 86 & 64 & 67 & 62 \\
Grandparents & 46 & 55 & 62 & 51 \\
School teachers & 54 & 30 & 35 & 30 \\
Aunts and uncles & 28 & 27 & 31 & 22 \\
Other relatives & 34 & 21 & 23 & 19 \\
Friends & 21 & 11 & 10 & 12 \\
Community elders & 10 & 13 & 17 & 7 \\
Community & 17 & 9 & 17 & 5 \\
\hline
\end{tabular}

Cultural continuity in the form of language teaching is maintained primarily by the extended family and especially by parents and grandparents. Language education in schools is also important. 


\section{Source:}

A Portrait of Aboriginal Children Living in Non-reserve Areas: Results from the 2001 Aboriginal Peoples Survey, Ottawa: Statistics Canada, Catalogue 89-597-XIE, page I9

First Nations Regional Longitudinal Health Survey (RHS) 2002/03: Results for Adults, Youth and Children Living in First Nations Communities, Ottawa: First Nations Centre, National Aboriginal Health Organization, 2005, Chapter 27, Figure I, page 237.

\section{Technical notes}

For children living in non-reserve areas, this question was asked only of those who spoke or understood an Aboriginal language. This restriction was not in place for those living on reserve.

TABLE 31

Residential School Attendance for Aboriginal Adults Living Off-Reserve, and for First Nation Adults Living On Reserve

\begin{tabular}{ll}
\hline Proportion of Adults Attending & Per cent \\
\hline First Nation Adults Living on Reserve & 20.3 \\
First Nation Off Reserve & 8.4 \\
Métis Off Reserve & 2.5 \\
Inuit & 13.0 \\
\hline
\end{tabular}

This chart provides information about the proportion of adults who attended residential school. The percentages may appear low, but that is due to the fact that residential school survivors are now senior citizens, and many have passed away. A breakdown of these figures by age group reveals, for example, that among First Nation adults living on reserve in 200203, the proportion of those 50 years and over who attended residential schools approaches 50 per cent.

\section{Data Sources}

Information for the off reserve population comes from the Aboriginal Peoples Survey, 2001, Statistics Canada, Catalogue 89-592-XIE, Tables 7, II and I5.

Data for the on reserve population is from First Nations Regional Longitudinal Health Survey (RHS) 2002/03: Results for Adults, Youth and Children Living in First Nations Communities, Ottawa: First Nations Centre, National Aboriginal Health Organization, 2005, Chapter I3, p. I34.

\section{Technical notes:}

The Aboriginal Peoples Survey defines adults as those 15 years of age and over. In the Regional Health Survey, adults are considered to be I8 years of age and over. 



\section{References}

I. Young, T. K. (I988). Health Care and Cultural Change. Toronto, ON. University of Toronto Press.

2. Adelson, N. (2005). The embodiment of inequality: Health disparities in Aboriginal Canada. Canadian Journal of Public Health, 96: S45-S6r.

3. Waldram, J., Herring, D. \& Young, K. (2006). Aboriginal Health in Canada $\left(2^{\text {nd }}\right.$ Ed). Historical, Cultural, and Epidemiological Perspectives. Toronto, ON: University of Toronto Press.

4. Wilson K. \& Rosenberg M. (2003). Exploring the determinants of health for First Nations peoples in Canada: Can existing frameworks accommodate traditional activities? Social Science \& Medicine, 55: 20I7-3I.

5. Royal Commission on Aboriginal Peoples (I996).Report of the Royal Commission on Aboriginal Peoples. Ottawa, ON: Supply and Services Canada.

6. Jenkins, A., Gyorkos, T., Culman, K., Ward, B., Pekeles, G. \& Mills, E. (2003). An overview of factors influencing the health of Canadian Inuit infants. International Journal of Circumpolar Health, 62(I): I7-39.

7. Young, T. K. (1994). The health of Native Americans: toward a biocultural epidemiology. New York, Oxford University Press.

8. Little, L. (2006) A Discussion of the Impacts of Non-Medical Determinants of Health for Inuit Mental Wellness (Draft). Ottawa, ON: Inuit Tapiriit Kanatami.

9. Steenbeek, A., Tyndall, M., Rothenberg, R., \& S. Sheps. (2006). Determinants of Sexually Transmitted Infections among Canadian Inuit Adolescent Populations. Public Health Nursing, 23 (6): 53I-534.

IO. Métis National Council (MNC) (2006). Proposals for Measuring Determinants and Population Health/Well-Being Status of Métis Peoples in Canada. Ottawa, ON: Métis National Council, March.
II. Young, T. K. (I996). Sociocultural and Behavioural Determinants of Obesity Among Inuit in the Central Canadian Arctic. Social Science and Medicine, 43(II): i665-I67I.

I2. Harris, S. B., Glazier, R. et al. (I998). Disease patterns among Canadian Aboriginal children - Study in a remote rural setting. Canadian Family Physician, 44: 1869-1877.

I3. Marmot, M. G. (2007). Mastering the control factor. Part two. The health report. Radio National.

I4. Syme, S. (1989). Control and health: a personal perspective. Bruselas: John Wiley \& Sons.

I5. Syme, S. (2004). Social determinants of health: the community as an empowered partner. Preventing Chronic Disease [serial online], I(I): I-5, http://www.cdc.gov/pcd/ issues/2004/jan/pdf/03_000I.pdf.

I6. Dennis, R(2004). Social determinants of health: Canadian perspectives. Toronto, ON: Canadian Scholars' Press.

I7. Marmot, M. (2005). Social determinants of health inequalities. Lancet, 365: 1099-I04.

I8. Edwards, P. (2007). The Social Determinants of Health: An Overview of the Implications for Policy and the Role of the Health Sector. Ottawa, ON: Health Canada.

I9. Syme, L. S. (2007). Mastering the control factor. Part one. The Health Report, Radio National.

20. Raphael, D. (2004). Introduction to the Social Determinants of Health. In Raphael, D. (Ed.), Social Determinants of Health: Canadian Perspectives. Toronto, ON: Canadian Scholars' Press Inc., I-I8.

2I. Wilkinson, R. \& Marmot, M. (I998). Social determinants of health: the solid facts. Geneva: World Health Organization. 
References continued

22. Galabuzi, G. (2004). Social Exclusion. In Raphael, D. (Ed.), Social Determinants of Health: Canadian Perspectives. Toronto, ON: Canadian Scholars' Press Inc., 235-252.

23. Canada Mortgage and Housing Corporation (2004). 200I Census Housing Series Issue 6: Revised Aboriginal Households. Research Highlight, Socio-economic Series 04-036. Ottawa, ON: CMHC, August.

24. Task Force on Aboriginal Languages and Cultures (2005). Towards a New Beginning: A Foundational Report for a Strategy to Revitalize First Nation, Inuit and Métis Languages and Cultures. Ottawa, ON: Aboriginal Affairs Branch, Department of Canadian Heritage.

25. Lawn, J., Langner, N. et al. Food consumption patterns of Inuit women. Int J Circumpolar Health I998; 57; Suppl ı: I98-204.

26. Little Bear, L. (2000). Jagged Worldviews Colliding. In Marie Battiste (Ed). Reclaiming Indigenous Voice and Vision. Vancouver, BC: UBC Press, pp 77-85.

27. Durie M. (2004). Understanding health and illness: Research at the interface between science and indigenous knowledge. International Journal of Epidemiology, 33:1138-43.

28. Richmond, C., Ross, N.A., \& Bernier, J. (2007). Exploring Indigenous concepts of health: The dimensions of Métis and Inuit Health. In J. White, D. Beavon, S. Wingert, \& P. Maxim (eds). Aboriginal Policy Research: Directions and Outcomes Volume 4. Toronto, ON: Thompson Educational Publishing. Forthcoming Spring.

29. Jenkins, A. L., Gyorkos, T. W. et al. (2003). An overview of factors influencing the health of Canadian Inuit infants. International Journal of Circumpolar Health, 62(I): I7-39.
30. Guo, S. S., Roche, A. F. et al. (1994). The predictive value of childhood body mass index values for overweight at age $35 \mathrm{y}$. The American Journal of Clinical Nutrition, 59(4): 8io.

3I. Moore, L. E., Wilson, R. T. et al. (2005). Lifestyle factors, exposures, genetic susceptibility, and renal cell cancer risk: a review. Cancer Invest., 23(3): 240-55.

32. Serdula, M. K., Ivery, D. et al. (I993). Do obese children become obese adults? A review of the literature. Preventive medicine, 22(2): 167 .

33. Blair, E. (1996). Why do aboriginal newborns weigh less? Determinants of birthweight for gestation. Journal of Paediatric Child Health, 32(6): 498-503.

34. Greenwood, M. (2005). Children as citizens of First Nations: Linking Indigenous health to early childhood development. Paediatric Child Health, Io(9): 553-555.

35. Kuh, D., Ben-Shlomo, Y. et al. (2004). A Life Course approach to Chronic Disease Epidemiology. New York: Oxford University Press.

36. Smith, G. D., Hart, C. et al. (1997) Lifetime socioeconomic position and mortality: prospective observational study. British Medical Journal (Clinical research ed.), 314(7080): 547.

37. Auger, N., Raynault, M. F., Lessard, R., and R. Choinière. (2004). Income and Health in Canada. In Raphael, D. (Ed.), Social Determinants of Health: Canadian Perspectives. Toronto, ON: Canadian Scholars' Press Inc. 2004: 39-52.

38. Wilson, K. \& Peters, E. (2007) You can make a place for it." Remapping urban Aboriginal spaces of identity. Environment and Planning D: Society and Space. In press.

39. Tjepkema, M. (2002). The health of the off-Reserve Aboriginal population. Health Report, I3: 73-88.

40. O’Donnell, V. \& Tait, H. (2003). Aboriginal Peoples Survey 2001 - Initial Findings: Wellbeing of the non-reserve Aboriginal Population. Ottawa, ON: Statistics Canada. 
4I. First Nations and Inuit Regional Health Survey National Steering Committee et al. (2004). First Nations and Inuit regional health surveys, 1997: a synthesis of the national and regional reports. Ottawa, ON: National Aboriginal Health Organization.

42. First Nations Information Governance Committee et al. RHS (2003). First Nations Regional Longitudinal Health Survey (RHS) 2002/2003 final report. Ottawa, ON: National Aboriginal Health Organization.

43. National Steering Committee for the First Nations and Inuit Regional Health Survey (I999). Final report. Ottawa, ON: National Aboriginal Health Organization.

44. McHardy, M, O. S. E. (200I). First Nations Community Well-Being in Canada: The Community Well-Being Index (CWB). Ottawa, ON: Strategic Research and Analysis Directorate Indian and Northern Affairs Canada.

45. Inuit Tapiriit Kanatami (ITK). (2004). Backgrounder on Inuit and Housing: For Discussion at Housing Sectoral Meeting, November $24^{\text {th }}$ and $25^{\text {th }} 2004$ in Ottawa. Ottawa, ON: Inuit Tapiriit Kanatami.

46. Young, T. K. and Mollins, J. (I996). The Impact of Housing on Health: an ecological study from the Canadian Arctic. Arctic Medical Research, 55: 52-6I.

47. McBride SR. (200I). Over-representation of Aboriginal students reported with behavioural disorders. A report to the Ministry of Education - British Columbia, Aboriginal Education Branch. Victoria, BC: Ministry of Education - British Columbia, Aboriginal Education Branch.

48. Canada Mortgage and Housing Corporation (2004). 200I Census Housing Series Issue 6: Revised Aboriginal Households. Research Highlight, Socio-economic Series 04-036. Ottawa, ON: CMHC, August.

49. Assembly of First Nations (2007) Draft Framework, Gender Balancing: Restoring our Sacred Circle. Ottawa, ON: Assembly of First Nations.
50. Karmali, S., Laupland, K, H., Findlay, C., Kirpatrick, A.W., Winston, B., Kotbeek, J., Crowshoe, L., \& Hameed. M. (2005). Epidemiology of severe trauma among status Aboriginal Canadians: a populationbased study. Canadian Medical Association Journal, I72(8): IOO7-IOII.

5I. Bernard, L., Lavallee, C. et al. (I995). Overweight in Cree schoolchildren and adolescents associated with diet, low physical activity, and high television viewing. Journal of the American Dietetic Association, 95(7): 800.

52. van Rossum, C. S., van de Mheen, H., Grobbee, D.E., \& Marmot, M.G. (2000). Employment grade differences in cause specific mortality. A 25-year follow-up of civil servants from the first Whitehall study. Journal of Epidemiology \& Community Health, 54: I78-I84.

53. Richmond, C., Ross, N.A. \& Egeland, G.M. (2007). Societal resources and thriving health: A new approach for understanding Indigenous Canadian health. American Journal of Public Health, October.

54. Kirmayer, L, Simpson, C., and Cargo, M. Healing Traditions: culture, community and mental health promotion with Canadian Aboriginal peoples. Australasian Psychiatry, II (SI): SI5-S23.

55. Health Survey National Steering Committee, et al. (2004). First Nations and Inuit regional health surveys, 1997: a synthesis of the national and regional reports. Ottawa, ON: National Aboriginal Health Organization.

56. Millar, W. J. (1992). Place of birth and ethnic status: factors associated with smoking prevalence among Canadians. Health Report, 4(I): 7-24.

57. Chan, A., Keane, R. J. et al. (200I). The contribution of maternal smoking to preterm birth, small for gestational age and low birthweight among Aboriginal and non-Aboriginal births in South Australia. Medical Journal of Australia, I74(8): 389-93. 
References continued

58. Ritchie, A. J. and Reading J. L. (2004). Tobacco smoking status among Aboriginal youth. International Journal of Circumpolar Health, 63(Supple. 2): 405-9.

59. Chan, A. K. and Robinson, J.S. (200I). The contribution of maternal smoking to preterm birth, small for gestational age and low birthweight among Aboriginal and non-Aboriginal births in South Australia. Medical Journal of Australia, I74(8): 389-93.

6o. Health Canada (2002). Fetal Alcohol Syndrome. Ottawa, ON: First Nations Inuit Health, Health Canada. Canadian Pediatric Society (2002). Fetal Alcohol Syndrome. Paediatric Child Health, 7(3): I6I-I74.

6I. Health Canada (2005). Fetal Alcohol Syndrome. Ottawa, ON: First Nations Inuit Health, Health Canada.

62. Campbell, A. (2002). Type 2 diabetes and children in Aboriginal communities: the array of factors that shape health and access to health care. Health Law Journal, IO: $147-68$.

63. Hanley, A. J., Harris S. B., et al. (2000). Overweight among children and adolescents in a Native Canadian community: prevalence and associated factors. The American Journal of Clinical Nutrition, 7I(3): 693.

64. Judd, N. L., Griffith, W. C. et al. (2004). Consideration of cultural and lifestyle factors in defining susceptible populations for environmental disease. Toxicology, I98(I-3): I2I-33.

65. Bryant, T. (2004). Housing and Health. In Raphael, D. (Ed.), Social Determinants of Health: Canadian Perspectives. Toronto, ON: Canadian Scholars' Press Inc., 2I7-232.

66. Morris, K., Morgenlander, M. et al. (I990). Wood-burning stoves and lower respiratory tract infection in American Indian children. American Journal of Diseases of Children, I44(I): I05-8.
67. Berghout, J., Miller, J. D. et al. (2005). Indoor environmental quality in homes of asthmatic children on the Elsipogtog Reserve (NB), Canada. International Journal of Circumpolar Health, 64(I): 77-85.

68. Strachan, D. P. (2000). The role of environmental factors in asthma. British Medical Bulletin, 56(4): 865-82.

69. Lawrence, R. and Martin, D. (200I). Moulds, moisture and microbial contamination of First Nations housing in British Columbia, Canada. International Journal of Circumpolar Health, 60(2): 150-6.

70. McIntyre, L., Connor, S. K. et al. (2000). Child hunger in Canada: results of the 1994 National Longitudinal Survey of Children and Youth. Canadian Medical Association Journal, I63(8): 96I-5.

7I. Chan, H. M., Fedliuk, K., Hamilton, S., Rostas, L., Caughey, A., Khnlein, H. Egeland, G. and Loring, E. (2006). Food Security in Nunavut, Canada: Barriers and Recommendations. International Journal of Circumpolar Health, 65 (5): 4I6-43I.

72. Lambden, J., Receveur, O., Marshall, J., and Kuhnlein, H. V. (2006). Traditional and Market Food Access in Arctic Canada is Affected by Economic Factors. International Journal of Circumpolar Health, 65 (4): 33I-340.

73. Moffatt, M. E. (I995). Current status of nutritional deficiencies in Canadian Aboriginal people. Canadian Journal of Physiology Q Pharmacology, 73(6): 754-8.

74. Nutrition Canada (1975). The Indian survey report: a report from Nutrition Canada. Ottawa, ON: Information Canada.

75. Lawn, J., Langner, N. et al. (I998). Food consumption patterns of Inuit women. International Journal of Circumpolar Health, 57 (Suppl I): 198-204.

76. Lawn, J. and Harvey, D. (2003). Nutrition and Food Security in Kugaaruk, NU:Baseline Survey for the Food Mail Pilot Project. Ottawa, ON: Ministry of Indian Affairs and Northern Development. 
77. Kuhnlein, H. V., Receveur, O. et al. (2004). Arctic Indigenous peoples experience the nutrition transition with changing dietary patterns and obesity. The Journal of Nutrition, I34(6): I447-53.

78. Indian and Northern Affairs Canada (2003). Water Quality and First Nations Communities (Backgrounder). Ottawa, ON. Indian and Northern Affairs Canada.

79. Anand, S. S., S. Yusuf, et al. (200I). Risk factors, atherosclerosis, and cardiovascular disease among Aboriginal people in Canada: the Study of Health Assessment and Risk Evaluation in Aboriginal Peoples (SHARE-AP). Lancet, 358(9288): II47.

8o. Barrett-Connor, E. (1989). Epidemiology, obesity, and non-insulin-dependent diabetes mellitus. Epidemiologic reviews, Iг: I72.

8I. Slattery, M. L. (2005). What is the role of diet in the development of cancer in American Indian and Alaska native populations? Journal of Cancer Education, 20(I Suppl): 92-6.

82. Murphy, N. J., Schraer, C. D. et al. (I995). Dietary change and obesity associated with glucose intolerance in Alaska Natives. Journal of the American Dietetic Association, 95(6): 676-82.

83. Reading, J. (2003). Unravelling the mystery of Type 2 Diabetes in the OjiCree. Canadian Journal of Diabetes, 27(3): 227-228.

84. Amling, C. L. (2004). The association between obesity and the progression of prostate and renal cell carcinoma. Urologic oncology, 22(6): 478-84.

85. Wortley, S. (2003). Hidden intersections: research on race, crime, and criminal justice in Canada. Canadian Ethnic Studies, 35 (3), 99-II7.

86. Galabuzi, G. (2004). Social Exclusion. In Raphael, D. (Ed.), Social Determinants of Health: Canadian Perspectives. Toronto, ON: Canadian Scholars' Press Inc., 235-252.
87. Daniel, M., Cargo, M. D. et al. (2004). Cigarette smoking, mental health and social support: data from a northwestern First Nation. Canadian Journal of Public Health, 95(I): 45-9.

88. Iwasaki, Y., Bartlett, J. et al. (2004). An examination of stress among Aboriginal women and men with diabetes in Manitoba, Canada. Ethnicity Q health, 9(2): I89-2I2.

89. Iwasaki, Y., Bartlett, J. et al. (2005). Coping with stress among Aboriginal women and men with diabetes in Winnipeg, Canada. Social Science \& Medicine, 60(5): 977-88.

90. Kirmayer, L. J., Brass, G. M. et al. (2000). The Mental Health of Aboriginal Peoples: Transformations of Identity and Community. Canadian Journal of Psychiatry, 45(7): 607.

9I. Mc Ewan, B. S. (2007). Good stress and bad stress. Mastering the control factor. Part three. The health report, ABS Radio National.

92. McEwen, B. (2006). Protective and damaging effects of stress mediators: central role of the brain. Dialogues Clinical Neuroscience, 8(4): 367-8I.

93. Chandler M.J., Sokol, L. C., and Hallett, B. (2003). Personal persistence, indentity development, and suicide: a study of Native and Non-native North American adolescents. Monographs of the Society for Research in Child Development, 68(2): I-I30, discussion I3I-I38.

94. O’Neil, J.D. (1994). Suicide among Canadian Aboriginal Peoples. Transcultural Psychiatric Research Review, 3I (I): 3-58.

95. O'Neil, J. D., Moffatt, M. E. K., Tate, R. B. et al. (I994). Suicidal Behaviour among Inuit in the Keewatin Region, NWT. In Petursdottir, G., Sigurdsson, S. B., Karlsson, M. M., Axelsson, J., eds. Circumpolar Health 93. Arctic Medical Research, 53 (suppl 2): 558-56r.

96. Tsey, K. (I997). Aboriginal selfdetermination, education and health: Towards a radical change in attitudes to education. Australian and New Zealand Journal of Public Health, 2I(I): 77-83. 
References continued

97. Smylie J., Williams L. and Cooper N. (2006). Culture-based Literacy and Aboriginal Health. Canadian Journal of Public Health, 97, S2I-S25.

98. Coryse, C. and Scott, K. (2006). The Determinants of Employment among Aboriginal Peoples. Ottawa, ON: Paper submitted to the Policy and Research Coordination Directorate, Strategic Policy and Planning Branch, Human Resources and Social Development Canada.

99. Condon, R. G. (1990). Adolescence and Changing Family Relations in the Central Canadian Arctic. Arctic Medical Research, 49: 8I-92.

Ioo. Holland Stairs, A. and Bernhard, J. (2002). Considerations for evaluating 'good care' in Canadian aboriginal early childhood settings McGill Journal of Education, 37(3): 309.

IоI. Cardinal, J. C. (2004). First Nations in Alberta, a focus on health service use. Edmonton, AB: Alberta Health \& Wellness.

I02. Newbold, K. B. (1997). Aboriginal physician use in Canada: location, orientation and identity. Health Economics, 6(2): 197-207.

I03. Health Canada (2007). Aboriginal Health: Current Initiatives. Ottawa, ON: Health Canada 2007.

I04. Archibald, L. and Grey, R. (2006). Evaluation of Models of Health Care Delivery in Inuit Regions. Ottawa, ON: Inuit Tapiriit Kanatami.

I05. McCormick, R. (1995/6). Culturallyappropriate means and ends of counselling as described by the First Nations people of British Columbia. International Journal for the Advancement of Counselling, I8(3): 163-172.

Io6. Browne, A. J. and Fiske, J.A. (200I). First Nations Women's Encounters With Mainstream Health Care Services. Western Journal of Nursing Research, 23: 126.
I07. Smye, V. and Browne, A. J. Cultural safety' and the analysis of health policy affecting Aboriginal people. Nurse Res., 9(3): 42-56.

I08. Assembly of First Nations (2005). First Nations Public Health: A Framework for Improving the Health of Our People and Our Communities. Ottawa, ON: Assembly of First Nations.

Io9. Korhonen, M. L(2006). Literacy and Health: The Importance of Higher-level Literacy Skills. Ottawa, ON: Ajunnginiq Centre, National Aboriginal Health Organization.

IIO. Ronson, B. and Rootman, I. (2004). Literacy: One of the Most Important Determinants of Health Today. In Raphael, D. (Ed.), Social Determinants of Health: Canadian Perspectives. Toronto, ON: Canadian Scholars' Press Inc., I-I8.

III. Greenwood, M., de Leeuw, S. and Ngaroimata Fraser, T. (2007). Aboriginal Children and Early Childhood Development and Education in Canada: Linking the Past and the Present to the Future. Canadian Journal of Native Education, 30 (I) 5-I8,I89-190.

II2. Tsey, K. (I997). Aboriginal selfdetermination, education and health: Towards a radical change in attitudes to education. Australian and New Zealand Journal of Public Health, 2I (I): 77-83.

II3. Postlethwaite, K. (2007). Boundary crossings in research: towards a cultural understanding of the research project 'Transforming Learning Cultures in Further Education'. Educational Review, 59 (4): 483.

II4. Dunn J. R., Hayes, M.V., Hulchanski, S. J., Hwang, D.W. and Potvin, L. (2006). Housing as a Socio-Economic Determinant of Health: Findings of a National Needs, Gaps and Opportunities Assessment. Canadian Journal of Public Health, 97 (Supplement 3):SII-Si5.

II5. Inuit Tapiriit Kanatami (ITK) (2004). Backgrounder on Economic Opportunities: For Discussion at the Economic Opportunities Sectoral Meeting, December $13^{\text {th }}$ and $14^{\text {th }}$, 2004 Ottawa, ON: Inuit Tapiriit Kanatami. 
II6. Senecal, S. (2007). Employment, Industry and Occupations of Inuit in Canada, 19812001. Ottawa, ON: Indian and Northern Affairs Canada.

II7. Mendelson, M. (2004). Aboriginal People in Canada's Labour Market: Work and Unemployment, Today and Tomorrow. Ottawa, ON: Caledon Institute of Social Policy.

II8. Folke, L. (2002). Resilience and Sustainable Development: Building Adaptive Capacity in a World of Transformations. T. E. A. Government.

II9. Tolbert Kimbro, R., Bzostek, S., Goldman, N., and Rodríguez, G. (2008). Race, Ethnicity, and the Education Gradient In Health. Health Affairs, 27(2); 36I-372.

I20. Assembly of First Nations (2006). Successful First Nation Policy Development: Delivering Sustainability, Accountability and Innovation. Ottawa, ON: Assembly of First Nations.

I2I. Chandler, M. J., and Lalonde, C. (I998). Cultural Continuity as a Hedge against Suicide in Canada's First Nations. Transcultural Psychiatry, 35: I9I-2I9.

I22. Krieger, K. (2008). Proximal, Distal, and the Politics of Causation: What's Level Got to Do With It? American Journal of Public Health, 98(2): 22I-30.

I23. Kelm, M. E. (1998). Colonizing bodies: Aboriginal health and healing in British Columbia, 1900-50. Vancouver, BC: UBC Press.

I24. Simon, R.I. and Eppert, C. (I997). Remembering obligation: pedagogy and the witnessing of testimony of historical trauma. Canadian Journal of Education, 22(2) I75.

I25. Assembly of First Nations (1994). Breaking the silence: An interpretive study of residential school impact and healing as illustrated by stories of First Nations individuals. Ottawa, ON: Native Tribal Health Consortium Cancer Program.
I26. Indian Residential School Survivors Society (2006). History. http://www.irsss.ca/history. html

I27. Adelson, N. (2005). The embodiment of inequity: health disparities in Aboriginal Canada. Canadian Journal of Public Health. Revue Canadienne de sante Publique, 96 Suppl 2: S45.

I28. Barnsley I. (2006). The right to health of indigenous peoples in the industrialized world: a research agenda. Health \& Human Rights. 9(I):43-54.

I29. Stephens C., Porter J., Nettleton C., and Willis R. (2006). Disappearing, displaced, and undervalued: a call to action for Indigenous health worldwide. Lancet, 367 : 2019-28.

I30. Mignone, J. (2003). Measuring Social Capital: A Guide for First Nations Communities. Ottawa, ON: Canadian Institute for Health Information.

I3I. Mignone, J. and O'Neil, J. (2005). Social capital and youth suicide risk factors in First Nations communities. Canadian Journal of Public Health, 96 (Suppl I): S5I-4.

132. Boyer, Y. (2006). Self Determination as a Social Determinant of Health. Discussion document for the Aboriginal Working Group of the Canadian Reference Group reporting to the WHO Commission on Social Determinants of Health. Hosted by the National Collaborating Centre for Aboriginal Health and funded by the First Nations and Inuit Health Branch of Health Canada. Vancouver: June 29.

I33. Madden J., Graham H., \& Wilson, J. (2005). Exploring Options for Métis Governance in the 21st Century. Ottawa, ON: Institute on Governance (IOG). September.

I34. Health Canada (2005). The statistical profile on the health of First Nations in Canada for the year of 2000. Ottawa, ON: Health Canada. 


\section{Table Sources}

TABLE 1 Sacha Senécal and Erin O'Sullivan, The Well-Being of Inuit Communities in Canada, a paper prepared for the Strategic Research and Analysis Directorate, Indian and Northern Affairs Canada, September, 2006, pp. 7 and $\mathrm{I} 3$.

TABLE 2 For data on First Nation adults on reserve, see Healthy Canadians: A Federal Report on Comparable Health Indicators 2006, Ottawa: Health Canada, p. 29. The data source is the Regional Health Survey, 2002-03.

All other data in the table is from the Canadian Community Health Survey (2000/OI) as reported in Michael Tjepkema, "The Health of the Off-reserve Aboriginal Population", Health Reports, Volume I3, 2002, supplement. Ottawa: Statistics Canada, Catalogue 82-003, Table 2, p.8

TABLE 3 Data for First Nation mothers living on reserve comes from the First Nations Regional Longitudinal Health Survey.

Data for Canadian mothers is from the National Longitudinal Survey of Children and Youth, 1998-99.

Both are reported in First Nations Regional Longitudinal Health Survey (RHS) 2002/03: Results for Adults, Youth and Children Living on First Nations Reserves, Ottawa: First Nations Centre, National Aboriginal Health Organization, 2005, p. 248.

TABLE 4 First Nations Regional Longitudinal Health Survey (RHS) 2002/03: Results for Adults, Youth and Children Living on First Nations Reserves, Ottawa: First Nations Centre, National Aboriginal Health Organization, 2005, p.I09
TABLE 5 For on reserve: First Nations Regional Longitudinal Health Survey (RHS) 2002/03: Results for Adults, Youth and Children Living in First Nations Communities, Ottawa: First Nations Centre, 2005, Chapter 3, Table 8, p. 44 .

For Canadian dwellings: Statistics Canada, Period of Construction, Structural Type of Dwelling, Housing tenure and Condition of Dwelling, 2006 Census, 20\% Sample Data, Catalogue No. 97-554-XCB2006022.

TABLE 6 I996 and 2006 Census as reported in Aboriginal Peoples in Canada in 2006: Inuit, Métis and First Nations, 2006 Census, Ottawa: Statistics Canada, Catalogue no. 97558-XIE.

TABLE 7 Statistics Canada, Topic-based Tabulations, Census topic number 97FooIIXCB2001045

TABle 8 Statistics Canada, Topic-based Tabulations, Census topic number 97FooIIXCB2001047

TABLE 9 Michael Tjepkema, "The Health of the Off-reserve Aboriginal Population", Statistics Canada, Catalogue 82-003, Supplement to Health Reports, Volume I3, 2002, Chart I, p. 5. Data is from the 2000/OI Canadian Community Health Survey.

TABLE 10 Data is from the Canadian Community Health Survey, 2000/OI, as reported in Michael Tjepkema, "The Health of the Off-reserve Aboriginal Population", Health Reports, Volume 13, 2002, supplement. Ottawa: Statistics Canada, Catalogue 82-003, Chart 4, Page 7.

TABLE 11 Statistics Canada, Topic-based Tabulations, Census topic number 97FooIIXCB2001043 
TABLE 12 Janet Che and Jiajian Chen, "Food Insecurity in Canadian Households", Health Reports, Vol. I2, No. 4, Ottawa, Statistics Canada, Catalogue 82-003.

TABLE 13 2000/OI Canadian Community Health Survey as reported in and adapted from Michael Tjepkema, "The Health of the Offreserve Aboriginal Population", Statistics Canada, Catalogue 82-003, Supplement to Health Reports, Volume I3, 2002, p. IO.

TABLE 14 Adapted from First Nations Regional Longitudinal Health Survey (RHS) 2002/03: Results for Adults, Youth and Children Living in First Nations Communities, Ottawa: First Nations Centre, 2005, Chapter I2, Table 3, p. 130.

TABLE 15 First Nations Regional Longitudinal Health Survey (RHS) 2002/03: Results for Adults, Youth and Children Living in First Nations Communities, Ottawa: First Nations Centre, 2005, Chapter I5, page I47 and Chapter 8, page 99.

tABLE 16 Aboriginal Peoples in Canada in 2006: Inuit, Métis and First Nations, 2006 Census, Ottawa: Statistics Canada, Catalogue no. 97558-XIE, Table 23.

tABLE 17 Aboriginal Peoples in Canada in 2006: Inuit, Métis and First Nations, 2006 Census, Ottawa: Statistics Canada, Catalogue no. 97558-XIE, Table I2.
TABLE 18 Aboriginal Peoples in Canada in 2006: Inuit, Métis and First Nations, 2006 Census, Ottawa: Statistics Canada, Catalogue no. 97558-XIE, Figure 5.

TABLE 19 First Nations Regional Longitudinal Health Survey (RHS) 2002/03: Results for Adults, Youth and Children Living on First Nations Reserves, Ottawa: First Nations Centre, National Aboriginal Health Organization, 2005, p. 35.

TABLE 20 First Nations Regional Longitudinal Health Survey (RHS) 2002/03: Results for Adults, Youth and Children Living in First Nations Communities, Ottawa: First Nations Centre, 2005, Chapter I3, Table 2 and pp. I34, I36.

TABLE 21 First Nations Regional Longitudinal Health Survey (RHS) 2002/03: Results for Adults, Youth and Children Living in First Nations Communities, Ottawa: First Nations Centre, 2005, Chapter I4, p. I39.

TABLE 22 First Nations Regional Longitudinal Health Survey (RHS) 2002/03: Results for Adults, Youth and Children Living in First Nations Communities, Ottawa: First Nations Centre, 2005, Chapter I4, Table 4, p. I42. 
Qhaving knomeledge. Shating a difference.

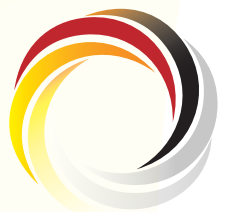

NATIONAL COLLABORATING CENTRE FOR ABORIGINAL HEALTH

CENTRE DE COLLABORATION NATIONALE DE LA SANTÉ AUTOCHTONE

3333 University Way, Prince George, B.C. V2N $4 Z 9$

Tel (250) 960-5986 Fax (250) 960-5644 Email: nccah@unbc.ca

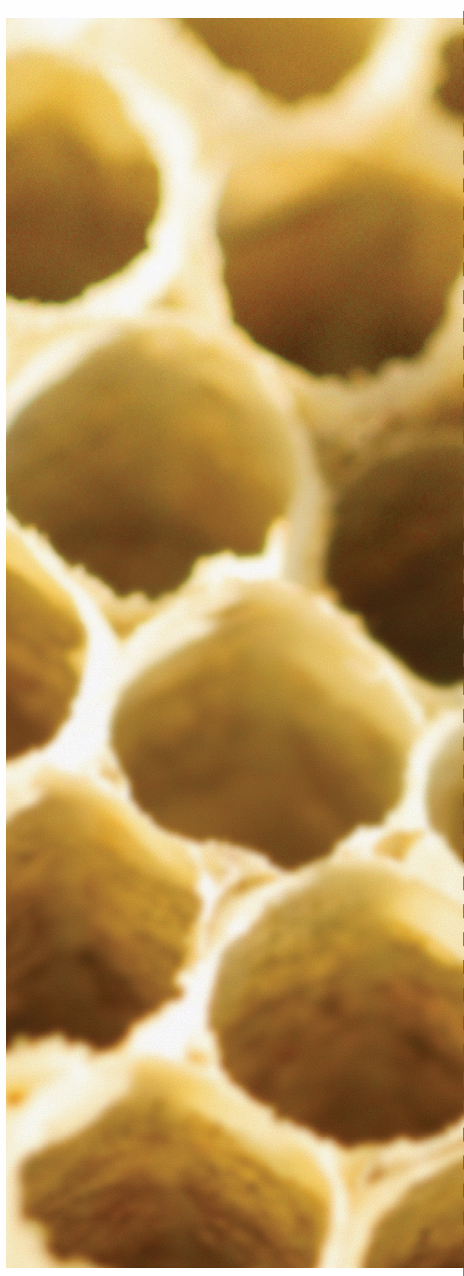

